\title{
TEFL in the Digital Age: The Use of Computer-Assisted Language Learning
}

\author{
Sanja Krimer Gaborović ${ }^{\text {and Josip Ivanović }}{ }^{2}$ \\ 'University of Novi Sad, Faculty of Civil Engineering in Subotica \\ 2University of Novi Sad, Hungarian Language Teacher Training Faculty in Subotica
}

\section{Abstract}

In the modern world, which has undergone an extensive technological revolution, the plurality of digital devices and electronic contents available, as well as a massive digitisation of information, knowledge and everyday communication have caused the convergence of communication and computing technologies. On this view, the paper aims at exploring how and why the digital resources can play a crucial role in assuming the new perspectives of Teaching English as a foreign language (TEFL). Since the denial of the advent of new ways for knowledge transmission is a failing classroom strategy in the long run, Information and Communications Technologies (ICT) should be embedded purposefully into the modern foreign languages classroom, with Computer-assisted language learning $(C A L L)$ being the new imperative of the good TEFL practice. By providing rich learning environment, CALL can increase the digital native students' interest and motivation. In this regard, the paper elaborates on the types of CALL applications in the EFL classrooms.

Key words: digital age; TEFL perspectives; Computer Assisted Language Learning (CALL)

\section{Introduction}

This paper is composed of two parts. The first part presents the view of the altered teaching and learning environment due to the rise of the electronic devices and the Internet. It reviews the concepts of Cyberspace and Cyberculture, with reference to the revolutionised language of the Internet (Applied Internet Linguistics as well as the use of emojis on Social Media). In the second part, some problems of teaching EFL in the digital age are discussed and an approach towards finding a solution is suggested 
in the form of Computer-assisted language learning (CALL). The reality is that the hyperconnected, quick-acting multitasking teens and young adults are no longer passive learners, but rather digital natives who live most of their life online. Thus, teaching EFL to them can no longer rely solely on traditional 'ex-cathedra' methods and acquiring factual knowledge.

\section{The Digital Age Epoch and the Rise of Digital Natives}

The $21^{\text {st }}$ century belongs to Cyberspace world (aka the digital information age). In this interactive and virtual environment the computing gadgets are abundant Smartphones, electronic organizers, digital music players and cameras, as well as all other tools and toys of the digital space. They are a commodity to their users; their profusion gives another fillip to their consumption.

The oceanic universe of information is also in a digital form, hence the new medium of digital communications arose through the global interconnection of computers (cf. Levy, 2001, p. xvi). The examples are as follows: e-mailing, chat, blogging, Facebook, Instagram, Twitter, WhatsApp, Youtube, etc. In this whole new world which has been created right before our eyes, a broad range of participants conduct business, engage in politics, promote and protect public health, social justice and human rights, as well as create intuitive media, among many other activities (cf. Technopedia, 2018; Phillips, 2015, p. 321). All of it changes our lives and affects our language. In fact, it gave rise to a new language as well as a new type of discourse along with it (Bogdan, 2012, p. 3).

As for Cyberculture, also called Internet culture, it has emerged, or is emerging, from the use of computer networks for communication, entertainment, and business. Cyberculture has been bred amongst those of us who are connected to the Internet (Flickr, 2015). It persists through online communications (Powell, 2017). Cyberculture embraces the set of practices, attitudes, modes of thought and values that grow along with the Cyberspace (Gómez-Diago, 2012).

The young people, more than any other age group, "use Information and Communications Technologies (ICT) to express their attitudes, values, beliefs and thinking" (Hollá, 2016, p. 40). Having grown up, or growing up, immersed in the new computerized surroundings, the web generation hardly ever stops to weigh and consider if things could be any different.

According to a recent study of 2,000 students between the ages of 8 and 18, students spend $71 / 2$ hours a day on average connected to some digital communication device, often to several simultaneously (Lewin, 2010). The techno era 'gave birth' to 'digital generation' - also known as the 'digital natives' who are all 'native speakers' of the digital language of computers, video games and the Internet (Prensky, 2001, p. 1).

As for the older Net users who do not possess digital brains (cf. Sprenger 2009, p. xiiixiv), in general anyone over the age of 40 , they form the group of 'digital immigrants' (Small \& Vorgan, 2008, p. 40-45) or perhaps, even more true to the current state of affairs, 'digital dinosaurs'. They did not reach their adulthood enveloped by the new 
technology, they must learn to adapt to their environment where face-to-face interaction has been replaced by the 'virtual' sphere of non-spatial interaction. A digital immigrant buys a new gadget and gets out the manual; a digital native buys a new gadget and just uses it (Tapscott, 2009, p. 10). A digital native edits their document written on the computer on the screen, a digital immigrant prints the document out in order to edit it (Prensky, 2001, p. 2). Despite the obvious immigrant/native dichotomy, nowadays there is an army of digital dinosaurs who are struggling to teach a population of digital natives. Indeed, modern-age teachers have the challenge of dealing with students who "are coming to school more literate in the new literacies of ICTs than their teachers" (Chandler-Olcott \& Mahar, 2003, p.361). As explained by Prensky, the teachers must, therefore, come out of their comfort zone to keep up with digital natives, and learn a whole new set of literacies (cf. Pegrum, 2009). Johnson (2015, p.14) warns, however, one should not automatically presuppose young teachers are automatically good, and like using digital technologies in their classroom. This would be an oversimplified, misleading conclusion as neither all teachers are digital immigrants nor all students are digital natives (Zur \& Zur, 2011).

\section{Digital Brains in Action: Multitasking or Hyperconnectedness}

In the Digital Age, a torrent of stimulation is just a click or touchscreen away. Even the slightest trace of boredom can be mitigated through constant screen connectivity. The extensive use of Cyberspace commodities affects cognition determining the value of what and how one thinks.

For the new breed of a digital native the desire to connect and be connected is irresistible. It is on this view that Masters $(2015$, p. 35$)$ comments: "The digital world offers a glittering promise of ubiquitous connectivity with friends, entertainment and information at our fingertips. It is not surprising that young people are choosing the online environment as a principal mechanism for socializing, communicating and exploring". In consequence, quick communication or the ability to respond fast is a highly prized asset. The Cyberculture messages are typically short, sequential, and directed. Reflexes are tuned to speed due to the increased speed of delivery on the Internet (Tapscott, 2009, p. 3-7).

A hallmark of the digital brain immersed in Cyberculture is multitasking or hyperconnectedness (Sprenger, 2009, p. 34). And to support and illustrate the point, let us picture a young person who may be skimming Game of Thrones, an American fantasy drama television series, on their tablet, while their smartphone is playing music by Taylor Swift, an American singer-songwriter. All of a sudden the youth is startled by a ring from the cell phone. It is his/her Mum. S/he answers the phone, but just then s/he gets a notification that someone has commented on his/her newly posted Instagram photo. While still on the phone, the young individual tries to read this text message from a classmate.

It is obvious from the previous short passage that, although hyperconnectedness was achieved, multitasking in fact failed as none of the work performed was actually 
carried out at 'full speed'. The inefficiency of multitasking is due to the fact that the brain cannot attend to more than one thing at a time (cf. Medina, 2008, 84-87, 90). It is also highly stressful in the long run.

Continuous partial attention (CPA) appears to be another culturally driven novelty, especially among the youth (Stone, 2013). Growing up in an age of entertaining distractions, the teens and young adults settle for quick, shallow choices, and lack patience. They are less likely to undertake deep, critical analysis of issues and challenging information (cf. Anderson \& Rainie, 2012). The problem of scattered attention and diffused concentration is becoming more and more common in our students' very inquisitive, yet also increasingly fidgety "wayward brains", the result of daily contact with the huge database on the Internet (Carr, 2008). Thus "all of us, but schools in particular, need to treat attention as a skill to be cultivated" (Levasseur, 2012). Digital natives should likewise be taught to ensure balance between the digital and physical world, or rather the world of instant communication and the world of human gifts.

\section{The Effects of the Electronic Revolution on Language}

Digital information world affects our daily lives and alters our language.

The main goal of language is communication - that is to say, the exchange of information. "Without language there would be no need for Facebook, Twitter, LinkedIn, or any of the other social networking media; Youtube would have only silent videos, and iTunes would be limited to instrumental music" (Samovar et al., 2013, p. 244). And language and culture, Cyberculture alike, are closely interwoven (Brown, 1994, p. 165).

Due to the growth of the Internet and the high-speed spread of fast broadband connectivity, the current digital era we live in is witnessing certain linguistic changes. Over the past decade, the World Wide Web rapid growth and the huge expansion of social networks have become an established genre of communication (Masters, 2015, p. 36). And it all "seem [s] to exert a pragmatic pressure on language [...]" (Giridharadas, 2010). The result of it all is form which pales in today's digital world. This is most obvious in e-mailing and instant messaging in chat rooms and/or on popular global social media. In the light of recent communication trends, James Morgan, a BBC journalist, reports on the event of 2011 when Giselle Barry, a US political figure, was e-mailing a group of reporters, to alert them to an important announcement, and she greeted them all with "Hey, folks". Ms. Barry claims such a casual salute suits her far better than to use "Dear..." in a work e-mail which is a bit too intimate and connotes a personal relationship. And as she strives to maintain what she calls "the utmost and highest level of professionalism", she sees no need for old-fashioned graces. The Wall Street Journal labeled this as the end of a centuries-old written tradition.

Having been inspired by the transparency of linguistic changes that occurred because of the digital age reign, the famous British linguist David Crystal (2005, p. 3) coined the term Applied Internet Linguistics.

Another important thing that the digital media push toward is a highly economical use of language (Wallace, 1999, p. 11). The young today are typically difficult to 
persuade that the accepted linguistic norms are worth obeying. After all, speaking and writing the standard does not come naturally to someone engaged in the tasks of the power-skimming, link-hopping and window-hopping which are so common in electronic communication (Carr, 2008). The Cyberculture messages are typically short, sequential, and directed, a mixture of often vowel-free abbreviations and acronyms. Examples of the erosion process by electronic devices are numerous and imminent, such as when one writes down $R U$ reading this? If you are, TIA. If you aren't, OMG! Get a life! which translates into: "Are you reading this? If you are, thanks in advance. If you aren't, oh my gosh (god)! Get a life!" The meaning of such abbreviations and acronyms may be hard to deduce, e.g. LOL can mean both laugh out loud and lots of love, and cryn can stand for both crayon and crying. In either case, the meaning needs to be grasped from the context.

The Internet slang is a new kind of "compressed" language and it prevails in electronic communication. An abbreviated verbal form is called for because the objective is to use the least number of characters needed to convey a comprehensible message. For example, text messaging coaxes one to misspell to meet the 160-character maximum. With a famous microblogging site Twitter, the situation is even worse (the total number of characters is mere 140). This reduction of the characters means that punctuation, grammar, capitalization, full sentences and the writing of words without numbers in them are largely ignored. Instead, technical terminology, jargon and mixed metaphors, abbreviations and acronyms, as well as entirely new punctuation marks become growingly common. Messages such as $t$ HanKz b'4 (thanks before) and call $u$ back after the mtg (I'll call you after the meeting) have earned the status of generally accepted lexis in the digital media. In Rimay's account (2010, p. 17), a single letter or digit will often replace a syllable with the electronic devices, e.g. ate, wait and tomorrow become $8, w 8$ and $2 m r o$, respectively. Another frequent thing is for single letters to replace words, e.g. see and are become $c$ and $r$, respectively. Words which have no common abbreviation are usually abbreviated by removing the vowels, hence dictionary becomes dctnry, whereas keyboard is reduced to kybrd.

Although the never-before-seen forms of communication may and commonly are dispraised, their existence should be acknowledged. It needs to be mentioned, furthermore, that electronic communication carried between today's youth is loaded with the examples where complete structure of the sentence is changed by eliminating the subject, verb or pronoun from it. As pointed out by Jovićević (2012, p. 367-368), "young generations actually change complete structure of the sentence [...] with the purpose of sending information as quickly as possible or keeping in track with modern trends". Overall, then, the grammar of such outputs must be inferred from the context, which is not always easily done.

\section{Emojis}

Another current trend in digital communication is the use of emojis or ideograms, designed to add emotional nuance to otherwise flat text and chilly electronic 
communication. These small icons compensate for the visual segment of interpersonal communication in text messages, emails and social media. An entire paragraph can be condensed into just a few emojis, which is undisputedly a highly practical approach to the electronic, finite-character text messaging ("A picture is worth a thousand words").

Emojis " $[. .$.$] are more than just cute pictures, these digital icons are a lingua franca$ for the digital age. [...] Today there are thousands of emoji depicting people in all their diversity, and thousands more to represent the things we interact with in our world [...]" (Pardes, 2018).

Before the birth of emojis, there were textual emoticons (a portmanteau of emotion and icon) to represent expressive human faces and emotions, like :) and :-) for a "smiley" or "happy face", or :( and :-( for a "sad face". An emoticon is, therefore, the sequence of punctuation marks, numbers and/or letters, e.g. in a smiley face represented by :-), the colon is the eyes, the dash is the nose and the right parenthesis stands for the mouth. One simply needs to tilt one's head to the left to grasp it all.

While emoticons conveyed simple emotions such as joy and sadness, the emojis made way for more complex symbols. The emoji pictures connote various types of things such as various facial expressions - winking eyes, frowning face, hearts of all shapes, sizes and colours, animals, common objects, flags, building, musical instruments, dresses, foods, symbols of religion, etc. (cf. Figure 1).

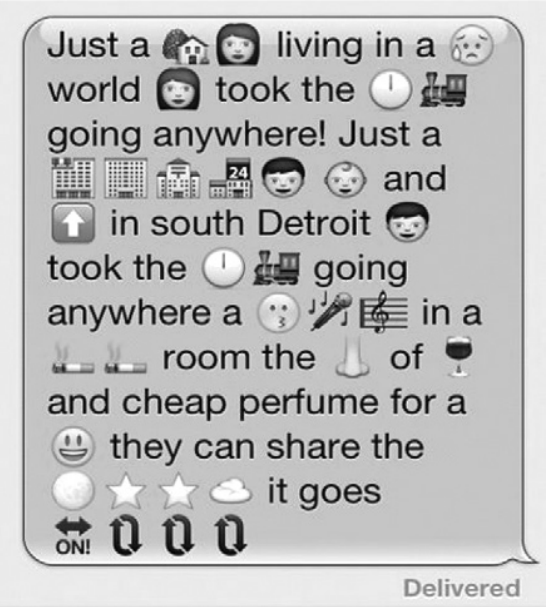

Figure 1. An Example of the Use of Emojis and Ideograms. (Source: https://www.pinterest.se/pin/603552787531549515/)

\section{The Role of English in Cyberculture}

As it was observed earlier, technology is rapidly changing language, habits and reasoning of the new generation of multitaskers. It is not the first time, however, the novel technological invention has revolutionized the ways in which humans perceive 
the world. Carr (2008) tells the story of the invention of the mechanical clock in the 14th century which has opened up a completely new dimension to how we perceive the time. Humans relied no more on their senses but on the time clocks which told them when to eat, to work, to sleep, to rise. And there are good reasons for believing the latest round of technological inventions is going to have even a bigger impact than its predecessors.

The Internet is an English-based network and most of the communication on it takes place in English (cf. Internet World Stats of December 2017 and its estimates for Internet Users by Language). English is, therefore, considered the "lingua franca" of the Internet. This is important to consider when we know "the status of a language depends not only on the number of speakers or books, films and TV stations that use it, but also on the presence of the language in the digital information space and software applications" (Tadić et al. 2012, p. 43). English is without doubt a prominent language taught all around the world (Akay, 2018, p. 432). It is the motivation behind the EFL learning since very early age, e.g. Helen Doron Early English Schools advertise English lessons for children as young as two. Obviously, the idea here is to better prepare children for the global world which is only to be even more closely interconnected in the future. To put it in other words, it is the revolution in communication technology which brings together people who speak different languages in new ways, and which also exerts pressure on individuals to learn new languages (Tadić et al., 2012, p. 46). According to Crystal (2003, p. 6), "about a quarter of the world's population is already fluent or competent in English, and this figure is steadily growing [...]. No other language can match this growth". [...] "Three times as many people [...] have learned English as a foreign language than have learned it at their mother's knee" (ibid, 1999, p. 230). This piece of information is to be viewed in the light of the fact that it has been estimated at least 2,000 languages of the world's 6,000 languages will not survive a globalized digital information society.

Nevertheless, the trend to use so much English seems to have inspired also the birth of a basic or "survival-level" English which is stripped-down of its true complexity (Favilla, 2017) - namely, rich and variegated lexicon, the wealth of idiomatic expressions and phrasal verbs, etc. In this sense, one might argue that English found on the web on social network sites, blogs and in chat rooms - is really only a deformed version of English. It is some special online or Cybercultural form of the language in question. Apparently, the Net is the escalator of English expanding as a lingua-franca, but not as a mother tongue. If to be truly fluent in a language means one is able to articulate a complex idea or tell an engaging story, then of course many youth clearly lack the skill. In fact, the practice of the domination of the English language seems to corrode the language of those who learn EFL. Giridharadas (2010) explains the "linguistic halfcastes" give up mastering their own language ending up "functional in many tongues without command of any". 


\section{Pros and Cons of the New Technology}

Existing dependence on digital equipment and electronic communications systems is all about: (1) convenience, since having the world's knowledge at one's fingertips comes in handy, and (2) entertainment, e.g. various online games played by Internet visitors. True, electronic (digital) media allow easy access to anyone or anything from pretty much anyplace, anywhere, anytime in the world. Being a highly informative environment, Cyberspace can be exploited for scientific and other research. Many of us already commonly research the answer to a question we do not know using our phone, computer, tablet, or lap top, rather than by looking for the answers in a book.

Times have changed and language, too, has become a digital thing, at least in its printed version. One of the arguments in favour of such a view is that all major book publishers offer eBooks, and that nearly all newspapers and magazines are available online. In his blogspot of 11 May 2010, Steve Wheeler, the Associate Professor of Learning Technology at Plymouth University, insists that new technology can do as much for us now as Gutenberg's Press did for people back in 1450. A mobile reading application Bookmate, that is filled with thousands of ebooks and audiobooks in 12 languages, can in fact encourage reading habits among young EFL learners. In Wheeler's words, digital resources are easier to transport, easier to store and retrieve, and they can be shared more readily. Students can submit their assignments online, in digital format. Moreover, it becomes much easier to check for plagiarised work. A teacher can, furthermore, colour code his/her remarks and attach them to student work for them to have clear and instant feedback on how well they have done and what they need to do to improve their work for future submissions. Indeed, teaching possibilities here are numerous.

Even though, a great development of digital technology has led us to various advances, with the good also comes the bad. In spite of the democratisation of access to information, students in the Digital Age can have great difficulty accessing quality information, they do not have enough time to absorb and make sense of information they receive, they frequently multitasks during learning situations which is a barrier to learning, etc. A harmful effect of online communication is particularly serious if the time spent online comes at the expense of other, more valuable offline activities, which eventually leads towards addictive, socially isolating behaviour. For example, a teen can be spending hours online chatting with strangers or engaging in the activity of online gaming instead of hanging out or playing sports with friends from school (Kraut \& Kiesler, 2003, p. 10). With the passing of time, the ability to communicate otherwise but digitally may be lost. This can be a trigger for social anxiety (feeling of dependency), problems in communication and learning, loneliness, lowered selfesteem, or chronic depression (cf. DeRushia, 2010, p. 4).

Additionally, the Net is such an incredibly rich store of information that it actually means texts from many sources online are typically only skimmed, not read. By 
adolescence, today's young people have become experts at skimming and scanning. On average, a person spends two seconds on each Web site when searching for information (Small \& Vorgan, 2008).

According to Carr (2008), for someone used to "foraging in the Web's info-thicket's reading and writing e-mails, scanning headlines and blog posts, watching videos and listening to podcasts, or just tripping from link to link", strolling down through long stretches of prose such as War and Peace is the mission impossible. Following the same line of thought, Ralph Fiennes, an English actor, blames electronic ways of communication for diluting modern language "so that the sentence with more than one clause is a problem for us, and the word of more than two syllables is a problem for us" (Jones, 2011). The celebrated actor furthermore remarks that thanks to social networking sites, that is to say, communication which is limited just to texting, e-mailing, instant messaging and blogging, students at drama schools seem to "find the density of a Shakespeare text a challenge in a way that, perhaps, (students) a few generations ago maybe wouldn't have" (ibid).

\section{Teaching EFL in the Digital Age}

It has been mentioned several times already that the young brain in a computerdominated world has been reprogrammed to the full. We as teachers are so familiar with its manifestations, the most obvious being concentration which quickly drifts away, at least when it comes to listening to long lectures.

Society has integrated digital technology into every aspect of human life and EFL teachers can no longer ignore the fact. In the digital age, it is thus imperative that a teacher should find ways to integrate technology in his/her practice. Digital media is easily accessible and quick to entertain young brains which become overwhelmed with the pervasive and hyperabundant information, its result being student distraction and impatience in tech-free classrooms. Various applications come in handy here. For example, translation accuracy in EFL classroom (although beginner to max intermediate level) can be checked by installing iTranslate, TripLingo or SayHi Translate which can translate any word or sentence directly from the Android device (a student simply writes on the screen or speaking into the microphone a word, sentence, text that $\mathrm{s} / \mathrm{he}$ wants to have translated).

In spite of foundational shifts both in the world and in the young digital brain, schools have changed very little in recent decades (Levasseur, 2011). A great majority still adhere to chalk and talk approach that was designed to tackle the environmental, social and economic challenges of the industrial world, not the digital era. New technologies are being used mostly to reinforce outmoded approaches to learning (Resnick, 2002, p. 32). Students are typically expected to follow slavishly the mantras of the previous generation, to acquire and reproduce the knowledge, which is disseminated by their teacher (Laurillard, 2002, p. 135). Nevertheless, since neither today nor tomorrow are what they used to be, digital natives cannot be taught applying solely the traditional 
method of teaching anymore. A digital native who has been networked most or all of their life has little patience for lectures, step-by-step logic, and "tell-test" instructions. They are used to the instantaneity of hypertext, downloaded music, phone in his/her pocket, a library on the laptop, beamed messages and instant messaging (Prensky, 2001, p. 3). A digital native wants information quick or else s/he will lose a tread and look for something else to do. This, of course, means the EFL methodology needs to adapt and reinvent itself, especially because the digital age has certainly opened new gates not only to human communication, but also language learning. Students need to be able to participate in a wide range of critical and creative educational practices involving technology and media.

In sum, the digital age has prompted the need for new teaching approaches and skills (cf. Compton, 2009). All teachers, the EFL teachers alike, need to take an open, flexible approach to digital equipment and electronic communications systems if their teaching is to make sense (cf. Gottschalk, 2010, p. 501). It is necessary for teachers to become familiar with new computational technologies and also the digital dialogue if they are to build stronger relationships with their students. Only then will the teachers be able to understand and relate better to the youth they are educating (Sprenger, 2009.p. 34). The bottom line: the obsession with the tech commodities will persist; as a matter of fact, it will expand. On the horizon, augmented and mixed reality, 3D printing and other innovations are heading in our direction. If we agree with Ralph Ellison's remark that "education is a matter of building bridges", then we should also wholeheartedly support Levasseur's comment (2011) that "no bridge is more important than the bridge to the future". Since in the current state of affairs that future is digital, educators must rethink teaching and learning EFL relying more extensively on digital technologies.

\section{Reinventing the EFL: From Teacher-Centered to Learner-Centered Education}

The TEFL world is increasingly moving online and EFL teachers are now able to share, collaborate and be inspired online like never before. It is beyond doubt that computers are revolutionising, and will revolutionise, how people learn a foreign language. Even though, integrating digital technologies into classrooms practice has not been a simple process (Mishra \& Koehler, 2006, 1018; Akay, 2018, p. 431).

The new media enables centering of the learning experience on the individual rather than on the transmitter. Learner-centered education improves the student's motivation to learn. The Net Generation in particular prizes freedom and freedom of choice. They enjoy a conversation, not a lecture. They want to have fun, even at school (Tapscott, 2009 , p. 6-7). Fun here means receiving information really fast, paralleling process and multi-task, having graphics precede the text rather than the opposite, randomly accessing (like hypertext), networking, instant gratification and frequent rewards, etc. (Prensky, 2001, p. 2). Pleasure, after all, must be part of the learning if learning is to work. The rationale behind it is the teacher development. Following Fullan (2006, 
p. 324), the process means "develop[ing] new insights into pedagogy and their own practice, and explor[ing] new or advanced understandings of content and resources".

Although technology is the reliable source of pleasure for the young generation, in the long run it should not be the only source of pleasurable experiences in learning environments. To go to extremes would be counterproductive. In this regard, Phillips (2015, p. 318) warns about the often uncritical praise of the use of digital technologies in classrooms, which is claimed to "have the capacity to enhance [...] teaching and learning [...]". Ironically, advertising campaigns advocating educational use of digital technologies, predominantly in developed western countries, are commonly sponsored by digital hardware and software companies. It is essential, therefore, that the EFL teacher should employ the interplay between three forms of knowledge: technological knowledge, pedagogical knowledge and content knowledge (TPACK) (Mishra \& Koehler, 2006, p. 1025), whereas the EFL students should be encouraged to balance the use of digital tools with face-to-face communication (activities). Otherwise, the students might end up meeting only as avatars completely forgetting that there are real people with real emotions on the other side of the screen (cf. Gottschalk, 2010, p. 501). Overall, then, students need to practice staying focused and listening attentively to the other, making eye contact, and not interrupting. This should help them build up socialemotional literacy which they typically lack. Moreover, it is important for students to be stimulated to allow their minds to get caught up in the narrative or the turns of the argument once again. But to achieve this, both high-tech and low-tech activities need to be included in the EFL classrooms. This of course implies not only that a teacher is computer literate and is using digital technologies in the classroom, but that $\mathrm{s} / \mathrm{he}$ incorporates digital technology effectively into the classroom practice (cf. Phillip, 2015, p. 319). "Such a teacher is more capable of transferring knowledge to students, since it is easier for him to implement modern methods and techniques [...]. In addition, such a teacher constantly communicates with students, since his availability to the students is not limited by time or place" (Dobrota \& Benković, 2014, p. 94). To put it simply, although "technology won't replace teachers, teachers who use technology will probably replace teachers who don't" (the statement was made at Learning through Technology Conference which was held in Glasgow, on 26-27 March 2013).

In our role as teachers, we have come to experience the benefits of introducing technology and media into the classroom first hand. Starting off with the classic textbooks repels the new generation, relying on the Internet and other electronic tools naturally inspires them. The mechanism behind the phenomenon is clear: the Net Generation seems to feast on technology and have an aptitude for all things digital (Tapscott, 2009, p. 10). Taking advantage of free online tools that make teaching easier is a wonder of the digital age teaching. The conclusion clearly follows that a complete denial of the advent of electronic texts, music, films, etc. - all of which have become a new way for knowledge transmission - is a failing strategy in the long run. The listed resources should instead be employed for the benefits of teaching EFL. IT-supported 
teaching methods and techniques (cf. Dobrota \& Benković, 2014, p. 94), however, first demands for the curriculum to be liberated (Krimer-Gaborović, 2009, p. 321), and then also for Computer Assisted Language Learning (CALL) to be widely introduced into the classrooms (Mišić-Ilić \& Mihajlović, 2011, p. 470). While the former measure implies making extensive use of audio-visual materials, PowerPoint presentations, research methods, and others, in connection with the topics of interest (it always depends on the target audience's abilities, skills, knowledge and preferences), the latter aims at introducing more practically-oriented courses that will integrate contemporary information technology into teaching and learning EFL. For example, a student(s) working on a research paper (or project) can be taught how to purposefully search and surf the great databases of the Internet, how to evaluate, modify and use the retrieved material, and how to exploit the possibilities of computer mediated communication and distance learning, all this for the benefit of learning EFL. It is a shift from teachercentered to learner-centered education. A teacher is still present in the learner-centered context; s/he is essential for creating and structuring the learning experience.

Let us now turn to first briefly reviewing practical implications of liberating the EFL curriculum, then in connection to it considering concrete examples of CALL in teaching EFL. If the curriculum is conceived of as everything that goes on in a school, then it has a more dynamic aspect. After all, learning is inherently nomadic, volatile and dynamic. This confirms our students' digital expertise can be put to practice only by adapting the EFL course to match the richness of data on the Web. In Levasseur's words (2011), a major educational goal in the $21^{\text {st }}$ century should be to form a clear and comprehensive view of the world. It altogether implies that modern education should aim at cultivating digital or new media literacies (traditional literacy is foundational, but it is no longer sufficient). It also implies working collaboratively within social networks, pooling knowledge collectively, navigating and negotiating across diverse communities, and critically analyzing and reconciling conflicting bits of information - which may be coded orally, in text, images, simulations, etc. Therefore, when dealing with a particular topic, such as engaging in the simple EFL classroom activity of teaching students the new weather lexis, the old style or ex cathedra lectures, where the teacher is the knowledge provider, should be abandoned. Instead, students need to be instructed and encouraged to google the Net in order to find information on weather phenomena. A resourceful online site here is the song lyric themes page where song lyrics can be searched for theme ideas. A vast majority of the available materials are already posted in English which makes the task of teaching EFL this way a truly enjoyable activity.

Such a method of lesson introductions will immediately encourage a student's active involvement in addressing the issues s/he is to become familiar with. The wise EFL teacher will always remember computer is the Net generation's most trusted companion. In general, CALL supported EFL activities allow "the learner to make choices and thus provides autonomy, a sense of empowerment, and the opportunity to become 
an active participant in language learning" (Furstenberg, 1997, p. 22). It also helps if students are accustomed to being split into pairs, threes, or work teams rather than running an errand on their own. This will promote their face-to-face communication. In case of a home assignment, group members may have to relate and communicate also through phone links, via email or other electronic communication, as well as in person, or a combination of these.

As a last point, it has to be noted that although the written language of the Internet and text messages is typically non-standard, the EFL teacher needs to have a truly broad vision of the purposes which such a language should serve. In short, the teacher should start with allowing "a stretch of language" only to arouse students' interests in EFL studying and help them stayed focused. Given that, EFL students will most certainly enjoy playing for example emoji puzzle games where they are to take emojis, put them together, and let others guess the meaning which is then spelled out. Once interest is aroused, the first teaching goal is achieved, and the EFL lecturing is free to move towards the art of talking about language more seriously. If not, contemporary multi-taskers will be hard to convince that formal language and literary style are worth dealing with at all.

\section{Addressing the Problem: Gadgets Which Make EFL Teaching Easier}

New gadgets or free online tools that make teaching more simple, better, or just more fun, pop up on the Net every day (Starr, 2012). These are the best ways to maximize the effectiveness of technology in the language classroom. The EFL teachers must engage with the tools if they are to draw out EFL teaching/learning benefits from within the digital chaos and terror. What follows is the list of networking EFL tools which is by no means complete (it is based primarily on the works by Starr (2012) and Tynan (2005)):

Motivator: a tool which allows the EFL teachers to create a motivational-style poster in about three minutes. An inspirational poster can be created by uploading a photo, supplying a headline and short text, etc.;

Wordie: an EFL teacher selects any text or series of words, and pastes them into a box at the Web site. A graphic display of the word is then created, with the size of each individual word being determined by its frequency in the original word set. The tool can be used for example to display classroom rules and to display grade level content expectations for classes. Additionally, students can rely on the tool to create unique book reports, language study notes, or perhaps to analyze their writing for overused words, etc;

WordSift: takes Wordle to another level. Once an EFL student (who happens to be also a struggling reader) enters his/her text, a word cloud is generated - as well as a word web and pictures;

Let Me Google That for You: a fun tool that both the EFL teachers and students like. If students (or teachers) have trouble finding certain information, such as information 
about the difference between a morpheme and a morph, this particular gadget can lead the way by suggesting appropriate sites concerning the topic;

Zap Reader: an online application to be used when one needs to consume large amounts of text quickly. Zap Reader allows users to copy and paste text into a text box and then "zap it". Essentially, what the program does is foster quicker reading speeds among less skilled readers, namely it increases the pace at which a student can read text silently. Over time, furthermore, the tool does not only build fluency through pacing, but it also stimulates increased comprehension. Students can start out at whatever pace is most comfortable for them and work their way up as their speed increases. Asking students to read aloud not only improves their oral reading fluency but it fosters reading expression as well;

Blogger: a free weblog publishing tool from Google, for sharing text, photos and video. It can easily be used as a communication springboard for out-of-class contests, research opportunities, extra-credit assignments, keeping absent students up-to-date, communication with parents about classroom climate, and much more. In addition to this, parents have found Blogger to be a wonderful tool for building motivation for out-of-school learning. The site walks users through how to build a blog, and it can be customized in a variety of ways;

Mindomo: an online mind mapping tool for visual learning, improving creativity and problem solving. Users can create idea flowcharts on whatever topic they would like; and then create subtopics, multimedia links, and more. YouTube videos show up right on the map which can be collapsed or expanded, looked only at one section at a time - the possibilities are endless. This tool comes in handy for the classroom projects, e.g. the study on families. Mind maps encourage brainstorming and understanding ideas revolving around a central topic, e.g. what aspects of family life do they feel are important to show through their projects (see Figure 2). With advanced EFL students it can also be concept maps in order to teach them how concepts are connected, e.g. Pyramids $\leftrightarrow$ Ancient Egypt $\leftrightarrow$ Royal Tombs $\leftrightarrow$ Burial Chambers $\leftrightarrow$ Death, and so on .

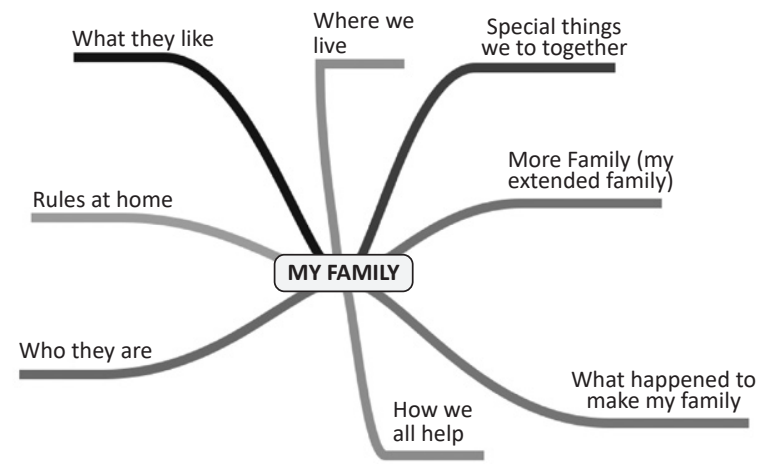

Figure 2. An Example of the Mind map Used in the Classroom. (Source: $h$ ttp://gradeoneproject.weebly.com/idea-web.html) 
To sum up, mind mapping teaches EFL students to explore and organize thoughts, ideas and information, and decide what is important and how it connects with what they already know. This is how they develop their critical thinking. Other mind map tools on the web worth considering are Mindmaps, Bubbl.us, Mindmeister, WiseMapping;

Grammarly: yet another handy tool to have and use. With its hypnotic editing powers Grammarly allows students to work on their writing skills by automatically providing solutions to misspelt words and sentences that do not make sense (it consistently points out mistakes);

Langroo: a user-friendly and accessible tool which serves as a 'native English friend', teaching a student conversational English used across the UK and US, no matter whether a student is a beginner looking for survival phrases or an advanced learner looking for 'hipster slang'. Conveniently located within Facebook Messenger, and with 24/7 availability, Langroo aims to defeat language barriers and mistranslations. With two accents - American and English - on offer, a student can switch between the two and establish a thorough understanding of the differences.

In general, gadgets which make EFL teaching easier could also be employed to help language learners enquire and discover for themselves. Instead of teaching students to answer, they should be taught to question more. After being confronted with timely and relevant questions, students should be encouraged to employ networking (and possibly) other available tools to find their own solution to the problem. This method fosters both critical thinking and functional skills and knowledge. Of course an EFL tutor should still be available to follow up, give feedbacks and response to queries.

Additionally, in problem-based learning, content tends to be learned deeply. Moreover, problem based EFL teaching/learning allows students to post their solutions (and the reasoning behind them) onto shared online spaces, where they will then have the task to defend their solution against criticism from the rest of the group. Of course, not everything can be taught/learned this way; for example, reading will not be dealt with by offering confusion so that students go online to debate their differing interpretations of what a word meant.

\section{Conclusion}

The paper touches on the position of English as a prominent language taught all around the world. English is also the lingua franca on the Internet and more recently it has been experiencing an exponential rate of change.

The paper also tries to examine in more details the various issues in teaching EFL to the new generation of students. The rapid growth of technology has brought many innovations in education and especially in EFL teaching. Since digital expertise is an important part of the digital native world, EFL teachers should start respecting the fact for the benefit of the EFL teaching. In the classrooms where CPA is currently a dominant attention mode, the traditional or ex-cathedra EFL teaching method needs to be given new freshness by introducing the CALL and Internet use. 
It also means that new language styles and forms that have arisen under the influence of the Internet and other digital media should be taken advantage of in order to awaken our students' interest in more serious language matters. Contemporary multitaskers can be convinced that formal language and literary style are worth dealing with, only if the EFL teacher allows "a stretch of language" to support curriculum projects, such as the creative use of Internet English, mixed metaphors, and the generic tools - Skype, Google, Tumbler, Twitter, Facebook, and blogs and wikis as well as technology-based tools for TEFL. This should help arouse students' interests in EFL studying and help them stay focused. Once these goals have been fulfilled, the teacher is to move towards the art of talking about language more seriously.

\section{References}

Anderson, J., \& Rainie, L. (2012). Millennials will benefit and suffer due to their hyperconnected lives. Internet \& technology. 29. Feb. 2012. http://www.pewinternet.org/2012/02/29/ millennials-will-benefit-and-suffer-due-to-their-hyperconnected-lives/

Bogdan, V. (2012). Language and the Internet. (Master's thesis). Osijek: Faculty of Philosophy. Brown, H. D. (1994). Principles of language learning and teaching. 3rd Edition. Prentice Hall Regents.

Carr, N. (2008). Is Google making us stupid? The Atlantic. July/August 2008. www.theatlantic. com https://doi.org/10.1111/j.1744-7984.2008.00172.x

Cenk, A. (2018). Digital drama versus digital story: Do they really affect pre-service EFL teachers' attitudes towards instructional technologies and material developing skills. Croatian Journal of Education, 20(2), 431-462. https://doi.org/10.15516/cje.v20i2.2636

Chandler-Olcott, K., \& Mahar, D. (2003). 'Tech-savviness' meets multiliteracies: Exploring adolescent girls' technology-related literacy practices. Reading Research Quarterly, 38, 356385. https://doi.org/10.1598/RRQ.38.3.3

Compton, L. K. L. (2009). Preparing language teachers to teach language online: a look at skills, roles, and responsibilities. Computer assisted language learning, 22(1), 73-99. https:// www.tandfonline.com/doi/pdf/10.1080/09588220802613831?needAccess=true, https:// doi.org/10.1080/09588220802613831

Crystal, D. (1999). A new linguistic world. In K. Ryan (Ed.), The Official Commemorative Album for the Millennium (pp. 228-231). Citroen Wolf Publications.

Crystal, D. (2003). English as a Global Language. $2^{\text {nd }}$ Edition. Cambridge University Press. https://doi.org/10.1017/CBO9780511486999

Crystal, D. (2005). The scope of Internet linguistics. www.davidcrystal.com

Dale, J. (2014). Teaching languages with technology: Tools that help students become fluent. The Guardian. https://www.theguardian.com/teacher-network/2014/may/13/modernforeign-languages-technology-tools-students-fluent

DeRushia, D. K. (2010). Internet usage among college students and its impact on depression, social anxiety, and social engagement. (Doctoral dissertation). IUP. 
Dobrota, M., \& Benković, S. (2014). Comparing 'ex-cathedra' and IT-supported teaching methods and techniques: Policy of teaching practice. Croatian Journal of Education, 16(3), 91-108. https://doi.org/10.15516/cje.v16i0.581

Favilla, E. (2017). How the Internet changed the way we write - and what to do about it. The Guardian. https://www.theguardian.com/technology/booksblog/2017/dec/07/internetonline-news-social-media-changes-language

Flickr, L. V. (2015). What exactly is Internet Culture? https://natandmarie.com/what-isinternet-culture/

Fullan, M. (2006). The new meaning of educational change. Fourth Edition. Columbia University: Teachers College Press.

Furstenberg, G. (1997). Teaching with technology: What is at stake? ADFL Bulletin, 28(3), 21-25. https://doi.org/10.1632/adfl.28.3.21

Giridharadas, A. 2010. Language as a blunt tool of the digital age. The New York Times. 15 Jan. 2010. www.nytimes.com

Gómez-Diago, G. (2012). Cyberspace and cyberculture. In M. Kosut \& J. G. Golson (Eds.), Encyclopedia of Gender in Media. SAGE reference publication http://www.sagepub.com/ books/Book235454\#tabview=title, https://doi.org/10.4135/9781452218540.n24

Gottschalk, S. (2010). The presentation of avatars in second life: Self and interaction in social virtual spaces. Symbolic Interaction, 33(4), 501-525. https://doi.org/10.1525/si.2010.33.4.501

Hollá, K. (2016). Cyberbullying as a negative result of cyber-culture of Slovak children and adolescents: selected research findings. Journal of Language and Cultural Education, 4(2), 40-50. https://doi.org/10.1515/jolace-2016-0015

Johnson, N. F. (2015). Digital natives and other myths. In M. Henderson \& G. Romeo (Eds.), Teaching and Digital Technologies: Big Issues and Critical Questions (pp. 11-21). Cambridge University Press.

Jones, L. (2011). Ralph Fiennes blames Twitter for eroding the language. The Telegraph. 27 Oct. 2011. http://www.telegraph.co.uk

Jovićević, J. (2012). Evolution of languages in cyber culture. Themes - Journal for Social Research, 1, 361-376.

Kraut, R., \& Kiesler, S. (2003). The social impact of Internet use. Psychological Science Agenda, 16(3), 8-10. https://doi.org/10.1037/e322322004-008

Krimer-Gaborović S. (2009). Engleski jezik kao jezik struke: Liberalizacija nastavnih sadržaja. [English as the foreign language: Liberating the curriculum]. In S. Hilčenko (Ed.), Nastava i Bolonjski proces. Zbornik radova sa 2. Međunarodne interdisciplinarne stručno-naučne konferencije (pp. 317-325). Subotica: Visoka škola strukovnih studija za obrazovanje vaspitača.

Laurillard, D. (2002). Rethinking university teaching: A new conversational framework for the effective use of learning technologies. EDUCAUSE Review, 37(1), 133-156. https://doi. org/10.4324/9780203160329

Levasseur, A. (2011). Learning in a digital age: Teaching a different kind of literacy. Mediashift. 4 Oct. 2011. www.pbs.org/mediashift

Levasseur, A. (2012). Why we need to teach mindfulness in a digital age. http://mediashift. org/2012/04/why-we-need-to-teach-mindfulness-in-a-digital-age095/ 
Lévy, P. (2001). Cyberculture. Translated by Robert Bononno, Minneapolis. University of Minnesota Press.

Lewin, T. (2010). If your kids are awake, they're probably online. The New York Times. 20 Jan. 2010. www.nytimes.com

Masters, J. (2015). Balancing risks and growth in a digital world. In M. Henderson \& G. Romeo (Eds.), Teaching and Digital Technologies: Big Issues and Critical Questions (pp. 3545). Cambridge University Press.

Medina, J. (2008). Brain rules: 12 principles for surviving and thriving at work, home, and school. Pear Press.

Mishra, P., \& Koehler, M. J. (2006). Technological pedagogical content knowledge: a framework for teacher knowledge. Teachers College Record, 108(6), 1017-1054. https://doi.org/10.1111/ j.1467-9620.2006.00684.x

Mišić-Ilić, B., \& Mihajlović, Lj. (2011). Učenje jezika uz pomoć računara kao novi akademski predmet. [Computer assisted language learning as a new academic course]. Primenjena lingvistika danas 3, 469-485.

Morgan, J. (2011). Should e-mails open with dear, hi, or hey?.” BBC News. 21 Jan. 2011. https:// www.bbc.com/news/magazine-12247262

Pardes, A. (2018). The wired guide to emoji. Culture. 2 Jan. 2018. https://www.wired.com/ story/guide-emoji/

Pegrum, M. (2009). From blogs to bombs: The future of digital technologies in education. UWA Publishing.

Phillips, M. Digital technology integration. In M. Henderson \& G. Romeo (Eds.), Teaching and Digital Technologies: Big Issues and Critical Questions (pp. 318-331). Cambridge University Press.

Powell, J. S. (2017). Cyberspace and cyberculture: Defining a new world. https://medium.com/ senior-seminar/cyberspace-and-cyberculture-12afc62ae05b

Prensky, M. (2001). Digital natives, digital immigrants - Part 1. On the Horizon, 9(5), 1-6. https://doi.org/10.1108/10748120110424816

Resnick, M. (2002). Rethinking learning in the digital age. In G. Kirkman (Ed.), Information technology report 2001-2002: Readiness for the Networked World (pp. 32-37). Oxford University Press.

Rimay, Z. (2010). Cybercultural communication. Tudományos Diákköri Konferencia. Faculty of Economic and Social Sciences. Budapest University of Technology and Economics.

Samovar, A. L., Richard, E. P., McDaniel, E. R., \& Roy, C. S. (2013). Communication Between Cultures. $8^{\text {th }}$ Edition. Cengage Learning.

Small, G., \& Vorgan, G. (2008). iBrain. Collins Living.

Sprenger, M. (2009). Focusing the digital brain. Teaching for the $21^{\text {st }}$ Century, 67(1), 34-39.

Starr, L. (2012). Our favorite gadgets. Education World. 23 April 2012. www.educationworld.com

Stone, L. (2013). Continuous partial attention. Linda Stone. http:/lindastone.net

Tadić, M., Brozović, D., \& Kapetanović, A. (2012). Hrvatski jezik u digitalnom dobu / The Croatian language in the digital age. Springer.

Tapscott, D. (2009). Growing up digital: How the net generation is changing your world. McGrawHill. https://www.techopedia.com/definition/2493/cyberspace 
Tynan, D. (2005). The 50 greatest gadgets of the past 50 years. PCWorld. 24 Dec. 2005. http:// www.pcworld.com

Wallace, P. (1999). The psychology of the Internet. Cambridge University Press. https://doi. org/10.1017/CBO9780511581670

Zur, O., \& Zur, A. (2011). Psychology of the web \& Internet addiction. Online Publication by Zur Institute. http://www.zurinstitute.com/internetaddiction.html

\section{Sanja Krimer Gaborović}

Department of Mathematics, Physics and Foreign Languages,

Faculty of Civil Engineering of Subotica

University of Novi Sad

Kozaračka 2a, 24000 Subotica, Serbia

krimer.sanja@gmail.com

\section{Josip Ivanović}

Department of Social Sciences and Humanities,

Hungarian Language Teacher Training Faculty of Subotica

University of Novi Sad

Strosmajerova 11, 24000 Subotica, Serbia

josip.ivanovic@magister.uns.ac.rs 


\section{Poučavanje engleskoga kao stranoga jezika (TEFL) u digitalnom dobu: uporaba računalno potpomognutih aplikacija}

\section{Sažetak}

U suvremenom svijetu, koji je pretrpio veliku tehnološku revoluciju, mnoštvo dostupnih digitalnih uređaja i elektroničkih sadržaja, kao i velika digitalizacija informacija, znanja i svakodnevne komunikacije, prouzročili su postupno približavanje svakodnevne komunikacije i računalnih tehnologija. U svjetlu tih navoda, cilj rada je istražiti kako i zašto digitalni resursi mogu igrati presudnu ulogu u prihvaćanju novoga pristupa poučavanju engleskoga kao stranoga jezika (eng. krat. TEFL). Budući da je negiranje pojave novih metoda širenja znanja dugoročno neuspješna strategija za poučavanje, informacijske i komunikacijske tehnologije (eng. krat. ICT), trebalo bi svrhovito biti ugrađene u modernu učionicu stranih jezika, gdje učenje (jezika) pomoću računala (engl. krat. CALL) postaje novi imperativ dobre TEFL prakse. $U$ stimulativnom nastavnom okruženju, primjena CALL-a može pospješiti interes $i$ motivaciju učenika koji su rođeni digitalci. S tim u svezi, rad se bavi primjenom vrsta CALL aplikacija u EFL učionicama.

Ključne riječi: digitalno doba; TEFL perspektive

\section{Uvod}

Ovaj se članak sastoji od dva dijela. U prvom dijelu komentira se izmijenjeno okruženje poučavanja i učenja zbog pojave elektroničkih uređaja i interneta. Raspravlja se i o konceptima kibernetičkoga prostora i kibernetičke kulture, uz osvrt na izmijenjeni jezik interneta (primijenjena internetska lingvistika kao i uporaba emojija na društvenim medijima). $U$ drugom dijelu govori se o nekim problemima poučavanja engleskoga kao stranoga jezika (eng. krat. TEFL) u digitalnom dobu te se predlaže pristup pronalaženju rješenja u obliku računalnoga učenja jezika (eng. krat. CALL). Današnji tinejdžeri i druga mladež nisu, naime, više samo pasivni učenici, već su to rođeni digitalci (eng. digital natives) koji vrijeme provode uglavnom na internetu, a odlikuju ih hiperkonektivnost ili hiperpovezivost (engl. hyperconnectedness) i višezadaćnost 
(engl. multitasking) to jest brzo reagiranje pri obavljanju više usporednih radnji. Stoga se TEFL kod takvih učenika više ne može oslanjati isključivo na tradicionalnu ekskatedra metodu i usvajanje znanja kroz prezentiranje gomile nesuvislih činjenica.

\section{Digitalna epoha i pojava rođenih digitalaca}

Odmah na početku treba istaknuti da 21. stoljeće pripada kibernetičkom svijetu (dobu digitalnih informacija). $U$ tom interaktivnom i virtualnom okruženju postoji mnoštvo računalnih naprava, poput pametnih telefona, elektroničkih organizatora, digitalnih glazbenih plejera i kamera, kao i svih ostalih alata i igračaka tipičnih za digitalni prostor. Za svoje korisnike ti proizvodi su potrošna roba čije izobilje potiče njihovo korištenje.

Pregršt informacija također je $\mathrm{u}$ digitalnom obliku, što je dovelo do rađanja novoga medija digitalne komunikacije kroz globalnu međusobnu povezanost računala (usp. Levy, 2001, str. xvi). Primjera je doista mnogo: e-pošta, chat, bloganje, društvene mreže Facebook, Instagram, Twitter, WhatsApp i dr., popularna mrežna usluga za razmjenu videozapisa Youtube itd. U tom posve novom okružju, stvorenom doslovce pred našim očima, širok krug sudionika vodi posao, bavi se politikom, promiče i štiti javno zdravlje, društvenu pravdu i ljudska prava stvarajući na taj način, između ostaloga, jedan intuitivni medij (usp. Technopedia, 2018; Phillips, 2015, str. 321). Sve to mijenja život suvremenoga čovjeka i utječe na jezik kojim se služi. U biti takve izmijenjenje okolnosti i dovele su do stvaranja novoga jezika i samim tim jednoga posve novoga diskursa (Bogdan, 2012, str. 3).

Što se tiče kibernetičke kulture, koja se naziva i internetska kultura, ona je nastala, ili još uvijek nastaje, iz upotrebe računalnih mreža za komunikaciju, zabavu i poslovanje. Korisnici interneta su ti koji daju zamašnjak kibernetičkoj kulturi (Flickr, 2015), a koja ustrajava zahvaljujući internetskoj komunikaciji (Powell, 2017). Kibernetička kultura obuhvaća skup postupaka, stavova, načina razmišljanja i vrijednosti koje rastu usporedo s kibernetičkim prostorom (Gómez-Diago, 2012).

Mladi, više nego ijedna druga starosna skupina, ,koriste informacijske i komunikacijske tehnologije (eng. krat. ICT) da bi izrazili svoje stavove, vrijednosti, uvjerenja i razmišljanja"' (Hollá, 2016, str. 40). Budući da je web generacija odrasla, ili još uvijek odrasta, uronjena u novo digitalno okruženje, gotovo se nikada ne zapita niti razmišlja o tome bi li stvari možda mogle biti i drukčije.

Prema nedavnom istraživanju koje je uključilo 2000 učenika u dobi između 8 i 18 godina, ispitanici prosječno provode po sedam i pol sati dnevno spojeni na neki digitalni komunikacijski uređaj, a često i na njih nekoliko istodobno (Lewin, 2010). Tehnološka era „izrodila” je ovu „digitalnu generaciju” poznatu kao „rođeni digitalci” ili „digitalni domorodci”, koji su svi „,izvorni govornici” računalnoga digitalnog jezika računala, videoigara i interneta (Prensky, 2001, str. 1).

\footnotetext{
${ }^{1}$ „,use Information and Communications Technologies (ICT) to express their attitudes, values, beliefs and thinking”.
} 
Kad je riječ o starijim korisnicima interneta koji ne poseduju digitalni mozak (usp. Sprenger 2009, str. xiii-xiv), općenito svi stariji od četrdeset godina života, oni čine skupinu tzv. „digitalnih imigranata” (Small i Vorgan, 2008, str. 40-45), ili možda još točnije „digitalnih dinosaura”. Ova skupina nije odrastala okružena novom tehnologijom, zbog čega digitalni dinosauri moraju naučiti prilagoditi se izmijenjenom okruženju u kojem je komunikacija licem u lice zamijenjena „virtualnom” sferom izvan prostornoga komuniciranja. Digitalni imigrant kupuje novi uređaj i vadi priručnik za uporabu, a rođeni digitalac kupuje novi gadget i odmah ga počne koristiti (Tapscott, 2009, str. 10). Rođeni digitalac svoj tekst napisan na računalu ispravlja na ekranu, dok digitalni imigrant tekst najprije ispiše pa ga tek onda uređuje (Prensky, 2001, str. 2). U suvremenom svijetu, unatoč očiglednoj dihotomiji između digitalnoga imigranta i rođenoga digitalca, cijela vojska digitalnih dinosaura ima zahtjevan zadatak poučavati novi naraštaj rođenih digitalaca. Današnji nastavnici suočavaju se, dakle, s izazovima poučavanja učenika koji „u pogledu informacijskih i komunikacijskih tehnologija u školu dolaze pismeniji od svojih učitelja"' (Chandler-Olcott i Mahar, 2003, str. 361). Kao što objašnjava Prensky, nastavnici moraju zbog toga izaći iz svoje zone komfora kako bi pratili rođene digitalce i moraju ovladati skupinom novih znanja (usp. Pegrum 2009). Međutim, Johnson (2015, str. 14) upozorava da se ne smije automatski pretpostaviti da su svi mladi nastavnici automatski kompetentni niti da svi rado koriste digitalne tehnologije u nastavi. To bi bio pogrešan i pojednostavljen zaključak jer niti su baš svi nastavnici digitalni imigranti, niti su baš svi učenici digitalni domorodci (Zur i Zur, 2011).

\section{Digitalni mozgovi u akciji: višezadaćnost i hiperkonektivnost}

U digitalnom dobu bujica podražaja dobija se jednostavnim klikom na dodirni ekran. Čak i najmanji osjet dosade može se ublažiti stalnom povezanošću s ekranom. Opsežna uporaba dobara iz kibernetičkoga prostora djeluje na spoznajne procese i utječe na vrijednost onoga o čemu čovjek razmišlja i kako to čini.

Za novu vrstu rođenih digitalaca želja da se povežu i ostanu povezani jednostavno je neodoljiva. Upravo to gledište komentira i Masters (2015, str. 35) „Digitalni svijet nudi divno obećanje o sveprisutnoj povezanosti s prijateljima, a zabava i informacije su na dohvat ruke. Stoga se ne trebamo čuditi da mladi ljudi biraju internetsko okruženje kao glavni mehanizam za druženje, komunikaciju i istraživanje". ${ }^{3}$ Posljedično, brza komunikacija ili sposobnost brzoga regiranja postaje vrlo cijenjena osobina. Poruke u kibernetičkoj kulturi obično su kratke, uzastopne i usmjerene. Refleksi su podešeni na brzo djelovanje zbog velike brzine protoka podataka na internetu (Tapscott, 2009, str. 3-7).

\footnotetext{
2 ,,are coming to school more literate in the new literacies of ICTs than their teachers".

3 ,The digital world offers a glittering promise of ubiquitous connectivity with friends, entertainment and information at our fingertips. It is not surprising that young people are choosing the online environment as a principal mechanism for socializing, communicating and exploring".
} 
Ključna obilježja digitalnoga uma uronjenoga u kibernetičku kulturu su višezadaćnost $\mathrm{i}$ hiperkonektivnost (Sprenger, 2009, str. 34). Da bismo potkrijepili i ilustrirali tu činjenicu, zamislit ćemo mladu osobu koja baca letimične poglede na svoj tablet na kojemu se prikazuje epizoda američke fantastične serije Igra prijestolja, dok s pametnoga telefona odjekuju zvuci pjesme Taylor Swift, američke pop zvijezde. Iznenada zazvoni telefon. $\mathrm{U}$ istom trenutku dok odgovara na telefonski poziv, naš/a djevojka/mladić dobiva obavijest da joj/mu je neko iz razreda prokomentirao novopostavljenu fotografiju na Instagramu. Dok nastavlja komunicirati preko telefona, istodobno nastoji pročitati i shvatiti sadržaj u međuvremenu pristigle SMS poruke.

Iz prethodnoga kratkog odlomka može se zaključiti da je hiperkonektivnost postignuta, ali ne i uspješna višezadaćnost budući da nijedan od zadataka nije odrađen „punom brzinom”. Neučinkovitost višezadaćnosti posljedica je činjenice da mozak ne može istovremeno obrađivati više zadataka (usp. Medina, 2008, str. 84-87, 90). Dugoročno gledano, to je i vrlo stresno.

Fenomen kontinuirane djelomične pažnje (eng. continuous partial attention, ili kraće - CPA) čini se kao još jedna kulturološka novost, posebice među mladima (Stone, 2013). Odrastajući u doba zabavnih sadržaja koji odvlače pozornost, današnji tinejdžeri i mladi pristaju na brze i površne izbore, a nedostaje im i strpljenja. Ne pokazuju sklonost prema dubokoj, kritičkoj analizi različitih tema i problema niti žele dovoditi u pitanje raspoložive informacije (usp. Anderson i Rainie, 2012). Djelomična pažnja i slaba koncentracija sve su češće kod vrlo radoznalih, ali istodobno pojačano nemirnih „samovoljnih umova” učenika, kao posljedica svakodnevnoga kontakta s golemom bazom internetskih podataka (Carr, 2008). Stoga se „svi mi, ali posebice škole, trebamo ophoditi prema pažnji kao prema vještini koju treba njegovati”" (Levasseur, 2012). Isto tako rođene digitalce treba učiti kako ostvariti ravnotežu između digitalnoga i tjelesnoga svijeta, točnije između svijeta brze komunikacije i svijeta ljudskih talenata.

\section{Učinci elektroničke revolucije na jezik}

Digitalni informacijski svijet utječe na svakodnevni život i mijenja jezik kojim govorimo. Glavni cilj jezika je komunikacija, to jest razmjena informacija. „Bez jezika ne bi bili potrebni ni Facebook, Twitter, LinkedIn, niti bilo koji drugi medij na društvenim mrežama. Youtube bi sadržavao samo video zapise bez zvuka, a iTunes bi bio ograničen na instrumentalnu glazbu”s (Samovar I sur., 2013, str. 244). I jezik i kultura, ovdje kibernetička kultura, usko su povezani (Brown, 1994, str. 165).

Zbog širenja interneta i sve veće globalne umreženosti ljudi, digitalno doba svjedoči određenim jezičnim promjenama. Tijekom protekloga desetljeća brzi rast svjetske internetske mreže i golema ekspanzija društvenih mreža postali su opće prihvaćeni žanr

\footnotetext{
${ }^{4}$,all of us, but schools in particular, need to treat attention as a skill to be cultivated".

${ }^{5}$ „Without language there would be no need for Facebook, Twitter, LinkedIn, or any of the other social networking media; Youtube would have only silent videos, and iTunes would be limited to instrumental music"
} 
komunikacije (Masters, 2015, str. 36). I sve to „kao da vrši pragmatični pritisak na jezik ${ }^{6}$ [...]" (Giridharadas, 2010). Rezultat je forma koja blijedi u današnjem digitalnom svijetu. To je najočitije u elektroničkoj pošti i izravnim porukama u ,sobama za čavrljanje” (chat rooms) i na popularnim globalnim društvenim medijima. U svjetlu nedavnih komunikacijskih trendova, James Morgan, novinar BBC-a, izvještava o događaju iz 2011. godine kada je Giselle Barry, američka političarka, skupini izvjestitelja poslala e-poruku s važnom obavijesti i pri tome ih pozdravila s „Bok ljudi!”. Gospođa Barry je smatrala da je takav neformalni pozdrav bio primjereniji poslovnoj e-komunikaciji od riječi „Dragi..., koja je preintimni način obraćanja i koja bi konotirala postojanje nekog osobnoga odnosa. I sve dok joj je cilj održati ono što naziva „najvećom i najvišom razinom profesionalizma"', ne vidi potrebu za staromodnim uljudnostima. Časopis Wall Street Journal ovaj je postupak označio kao kraj vjekovne tradicije.

Inspiriran transparentnošću jezičnih promjena kao posljedice vladavine digitalnoga doba, ugledni britanski lingvist David Crystal $(2005$, str. 3) skovao je pojam primijenjena internetska lingvistika (eng. Applied Internet Linguistics).

Druga važna činjenica na koju digitalni mediji stavljaju naglasak jest visoko ekonomična uporaba jezika (Wallace, 1999, str. 11). Danas je mlade uglavnom teško uvjeriti da se vrijedi pridržavati prihvaćenih jezičnih normi. Naposljetku, govoriti i pisati standardnim jezikom nije nešto što je prirodno nekome tko na brzinu bira sadržaje, učitava poveznice, otvara i zatvara prozore, što je potpuno uobičajeno u elektroničkoj komunikaciji (Carr, 2008). Poruke o kibernetskoj kulturi obično su kratke, uzastopne i usmjerene, mješavina su kratica i akronima koji često ne sadrže samoglasnike. Primjeri procesa erozije izazvani elektroničkim uređajima su mnogobrojni i neizbježni, primjerice kada netko napiše: $R U$ reading this? If you are, TIA. If you aren't, OMG! Get a life! što je kraćeno od: Are you reading this? If you are, thanks in advance. If you aren't, oh my gosh (god)! Get a life! to jest u prijevodu na hrvatski: „Čitaš li ovo? Ako da, hvala ti unaprijed. Ako ne, oh moj Bože! Daj počni živjeti!". Značenje takvih kratica i akronima katkad je teško zaključiti, npr. eng. LOL može značiti laugh out loud smijati se glasno i lots of love puno ljubavi, a cryn može označavati crayon bojicu i crying plač. U oba slučaja značenje treba shvatiti iz konteksta.

Internetski sleng nova je vrsta komprimiranoga jezika koji prevladava u elektroničkoj komunikaciji. Traži se skraćena verbalna forma jer je cilj koristiti što manje znakova da bi se prenijela razumljiva poruka. Na primjer, u tekstualne poruke unose se pogrešno napisane riječi da bi se zadovoljio kriterij maksimalnih 160 znakova. Na poznatoj stranici za mikrobloganje društvene mreže Twitter situacija je još gora (samo 140 znakova ukupno). Ovo smanjenje broja dopuštenih znakova znači da se uglavnom zanemaruju interpunkcijski znakovi, gramatika, velika slova, pune rečenice, a brojevi počinju zamjenjivati pojedine riječi. Sve se češće koristi tehnička terminologija, žargon

\footnotetext{
${ }^{6}$ „seem $[\mathrm{s}]$ to exert a pragmatic pressure on language $[\ldots]$ ”.

${ }^{7}$ „the utmost and highest level of professionalism”.
} 
i miješane metafore, kratice i akronimi, kao i potpuno novi interpunkcijski znakovi. Poruke poput $t \mathrm{HanKz} b 4$ (hvala unaprijed) i call $u$ back after the mtg (nazvat ću te nakon sastanka) stekle su status općeprihvaćenoga leksika u digitalnim medijima. Prema riječima Rimaya (2010, str. 17), na elektroničkim uređajima jedno slovo ili znamenka broja često zamjenjuje slog, npr. ate (jeli (smo)), wait (čekaj(te)) i tomorrow (sutra) postat će po redoslijedu pojavljivanja $8^{8}, w 8$ i $2 m r o$. Druga česta pojava je zamjenjivanje pojedinih cijelih riječi jednim slovom, npr. see (vidjeti) i are (smo, ste, su) postaju $c$ i $r$ po redoslijedu navođenja. Riječi za koje ne postoji uobičajena kratica obično se skraćuju uklanjanjem samoglasnika, pa dictionary (rječnik) postaje dctnry, dok se keyboard (tipkovnica) svodi na kybrd.

Iako smo ove nikad viđene oblike komunikacije spremni podcijeniti, što često i činimo, potrebno je priznati da oni ipak postoje. Potrebno je, nadalje, spomenuti da elektronička komunikacija između mladih obiluje primjerima u kojima se cjelovita rečenična struktura mijenja izbacivanjem subjekta, glagola ili zamjenice. Kako to ističe Jovićević (2012, str. 367-368) „mlade generacije zapravo mijenjaju cjelokupnu strukturu rečenice s ciljem što bržeg slanja informacija ili praćenja modernih trendova"9. Sve u svemu, gramatika takvih rečeničnih tvorevina mora se zaključiti iz konteksta, što nije uvijek jednostavno.

\section{Emojiji}

U aktualan trend digitalne komunikacije ubrajamo i uporabu emojija ili ideograma, osmišljenih da dodaju emocionalnu nijansu inače bezličnom tekstu i hladnoj elektroničkoj komunikaciji. Ove ikonice nadoknađuju vizualni segment međuljudske komunikacije u tekstualnim porukama, e-porukama i na društvenim medijima. Cijeli se odlomak može sažeti u samo nekoliko emojija, što je nesumnjivo vrlo praktičan pristup elektroničkom tekstu ograničenoga broja znakova jer slika govori više od tisuću riječi.

Emojiji „su više od simpatičnih slika. Te digitalne ikone su linga franca digitalnoga doba. Danas postoje tisuće emojija koji prikazuju ljude u svim njihovim raznolikostima, a tisuće ih još više prikazuje stvari s kojima čovjek kontaktira u svojem okruženju"10 (Pardes, 2018).

Prije nastanka emojija postojali su tekstualni emotikoni (paketići emocija i slike) koji predstavljaju izražajna ljudska lica i emocije, poput :) i :-) za „smiješak” to jest „sretno lice”, ili :( i :-( za „tužno lice”. Emotikon je, dakle, niz interpunkcijskih znakova, brojeva i/ili slova, primjerice na nasmiješenom licu čiji je prikaz ovakav :-), dvotočka su oči, crtica je nos, a desna zagrada predstavlja usta. Jednostavno je potrebno nagnuti glavu ulijevo da bi se to shvatilo.

\footnotetext{
${ }^{8}$ Prošlo vrijeme eng. glagola eat je ate i isto se izgovara kao i broj 8 (riječ je o homofonima).

${ }^{9}$ "young generations actually change complete structure of the sentence $[\ldots]$ with the purpose of sending information as quickly as possible or keeping in track with modern trends".

${ }^{10},[\ldots$ are $\mathrm{m}]$ ore than just cute pictures, these digital icons are a lingua franca for the digital age. [...] Today there are thousands of emoji depicting people in all their diversity, and thousands more to represent the things we interact with in our world [...]".
} 
Dok su emotikoni prenosili jednostavne emocije, poput radosti i tuge, emojiji su ustupili mjesto složenijim simbolima. Emojiji označavaju razne stvari, na primjer različite izraze lica - oči koje namiguju, namršteno lice i dr., srca svih oblika, veličine i boje, životinje, uobičajene predmete, zastave, građevine, glazbene instrumente, odjeću, hranu, vjerske simbole itd. (usp. Sliku 1).

Slika 1.

\section{Uloga engleskoga jezika u kibernetičkoj kulturi}

Kao što je ranije već istaknuto, tehnologija brzo mijenja jezik, navike i rasuđivanje novih višezadaćno orijentiranih korisnika (multitaskera). Ne događa se, međutim, prvi put u povijesti čovječanstva da je novi tehnološki izum revolucionirao način na koji ljudi doživljavaju svijet. Carr (2008) govori o izumu mehaničkoga sata u 14. stoljeću koji je otvorio potpuno novu dimenziju doživljaja vremena. Umjesto na svoja osjetila, ljudi su se počeli oslanjati na satove koji su počeli određivati kada trebaju jesti, raditi, spavati, ustajati. Postoje dobri razlozi za vjerovanje da će najnoviji krug tehnoloških izuma imati čak i veći utjecaj od svojih prethodnika.

Internetska komunikacija većinom se odvija na engleskome jeziku (usp. Statistika najčešće korištenih jezika na internetu (eng. Internet World Stats) iz prosinca 2017. koja je dala prikaz procijenjenoga broja internetskih korisnika prema jeziku). Engleski se, dakle, smatra jezikom sporazumijevanja na internetu. To je važno uzeti u obzir kad se zna da „[s] tatus jezika ne ovisi samo o broju njegovih govornika ili broju knjiga, filmova i TV-postaja koji se njime služe, nego i o prisutnosti toga jezika u digitalnome informacijskome prostoru i u adekvatnoj programskoj podršci” (Tadić, BrozovićRončević i Kapetanović, 2012, str. 1). Engleski je bez sumnje značajan jezik koji se uči u cijelom svijetu (Akay, 2018, str. 432). To je motiv za usvajanje EFL-a od vrlo rane dobi, npr. Helen Doron škola engleskog jezika za mališane (eng. Helen Doron Early English School) oglašava lekcije engleskog jezika za djecu od dvije godine. Očigledno je da postoji želja da se i najmlađi pripreme za globalni svijet koji će u budućnosti biti još više povezan. Drugim riječima, revolucija u komunikacijskoj tehnologiji okuplja ljude koji na novi način govore različite jezike i koja također vrši pritisak na pojedince da nauče nove jezike (Tadić, Brozović-Rončević i Kapetanović, 2012, str. 46). Prema riječima Crystala (2003, str. 6) „oko četvrtine svjetskog stanovništva već tečno ili vrlo dobro govori engleski jezik i ta brojka neprestano raste [...]. Nijedan drugi jezik ne može pratiti taj rast”. ${ }^{11}[. .$.$] „Tri puta više ljudi [...] naučilo je engleski kao strani jezik$ nego što ima onih koji su ga naučili u majčinom krilu”12 (ibid, 1999, str. 230). Taj podatak treba promatrati u svjetlu činjenice da je procijenjeno da barem 2000 jezika

\footnotetext{
${ }^{11}$ "about a quarter of the world's population is already fluent or competent in English, and this figure is steadily growing $[\ldots]$. No other language can match this growth".

${ }^{12}$ „Three times as many people [...] have learned English as a foreign language than have learned it at their mother's knee".
} 
od ukupno 6000 koji se danas govore u svijetu neće preživjeti globalizirano digitalno, to jest informacijsko društvo.

Ipak, čini se da je trend korištenja toliko engleskoga jezika također potaknuo rađanje osnovnoga engleskog, to jest engleskoga jezika „za preživjeti” (eng. survivallevel English), koji je lišen svoje prave složenosti (Favilla, 2017). Tu nema bogatoga ni raznovrsnoga leksika, bogatstva idiomatičnih izraza i frazalnih glagola itd. $U$ tom bi se smislu moglo tvrditi da je engleski jezik na internetu, to jest na društvenim mrežama, u bloganjima i chatovima, zapravo samo deformirana inačica izvornoga jezika. Riječ je o nekom posebnom internetskom ili kibernetičko-kulturnom obliku engleskoga jezika. Očito, internet je pokretač širenja engleskoga kao jezika sporazumijevanja, ali ne i kao materinskoga jezika. Ako stvarno tečno govori neki jezik, znači da je čovjek sposoban artikulirati složenu ideju ili ispričati zanimljivu priču na tom jeziku, onda mnogim mladima ta vještina očito nedostaje. Zapravo, čini se da dominacija engleskoga jezika nagriza materinski jezik onoga koji uči engleski kao strani jezik. Giridharadas (2010) objašnjava da su ,jezični mješanci” (eng. linguistic half-castes) odustali od ovladavanja vlastitim jezikom i završili tako što „funkcioniraju na mnogim jezicima bez pravog znanja ijednoga". ${ }^{13}$

\section{Prednosti i nedostatci nove tehnologije}

Postojeća ovisnost o digitalnoj opremi i elektroničkim komunikacijskim sustavima sastoji se u: (1) praktičnosti, budući da je zgodno imati svjetsko znanje nadohvat ruke i (2) zabavi, npr. raznim internetskim igrama. I doista, elektronički (digitalni) mediji omogućuju jednostavan pristup bilo kome i bilo čemu, gotovo bilo gdje i bilo kada u svijetu. Budući da je riječ o visoko informativnom okruženju, kibernetički prostor može se iskoristiti za znanstvena i druga istraživanja. Odgovore na pitanja koja ih muče, mnogi već uvelike traže na svojim telefonima, računalima, tabletima ili prijenosnim računalima umjesto u tiskanim knjigama.

Vremena su se promijenila i jezik je također postao digitalna pojava, u najmanju ruku barem u tiskanom formatu. Jedan od argumenata u prilog takvom stajalištu je da svi glavni izdavači knjiga nude e-knjige te da su gotovo sve novine i časopisi dostupni na internetu. U svojem blogu od 11. svibnja 2010. godine, Steve Wheeler, izvanredni profesor tehnologije učenja na Sveučilištu Plymouth, inzistira na tome da nova tehnologija može učiniti danas jednako toliko mnogo za čovjeka kao što je to Gutenburgova tiskara učinila 1450. godine. Mobilna aplikacija za čitanje Bookmate, koja sadrži tisuće e-knjiga i audioknjiga na dvanaest jezika, može zapravo potaknuti čitanje među mladim EFL polaznicima. Prema Wheelerovim riječima, digitalni se resursi lakše prenose, lakše ih se pohranjuje, pronalazi i dijeli. Učenici imaju mogućnosti poslati svoje zadaće preko interneta (u digitalnom obliku). Štoviše, postaje mnogo lakše provjeriti plagirani rad. Nastavnik može, nadalje, označiti bojom svoje primjedbe i proslijediti ih učenicima da bi oni odmah imali jasne povratne predodžbe o tome

${ }^{13}$ „functional in many tongues without command of any”. 
koliko su dobro nešto napravili i što trebaju učiniti kako bi ubuduće poboljšali svoj rad. Doista, mogućnosti poučavanja su brojne.

Iako je velik razvoj digitalne tehnologije doveo do napretka na različitim poljima, u svakom dobru ima i nečeg lošega. Naime usprkos demokratizaciji pristupa informacijama, učenici u digitalnom dobu mogu imati velikih poteškoća u pristupu kvalitetnim informacijama, nemaju dovoljno vremena za usvajanje i razumijevanje svih podataka koje dobivaju, učeći često rade više zadataka istovremeno što je prepreka učenju itd. Štetni učinak internetske komunikacije posebno je ozbiljan ako vrijeme provedeno na mreži ide na štetu drugih, vrjednijih izvanmrežnih aktivnosti, što na kraju vodi k ovisničkom, socijalno izolirajućem ponašanju. Na primjer, tinejdžer može provoditi sate na internetu razgovarajući s nepoznatim osobama ili igrajući internetske igre umjesto da se druži ili bavi sportom s prijateljima iz škole (Kraut i Kiesler, 2003, str. 10). Kako vrijeme prolazi, može izgubiti sposobnost komuniciranja na bilo koji drugi način osim u digitalnom obliku. To može biti okidač za socijalnu anksioznost (osjećaj ovisnosti), probleme u komunikaciji i učenju, usamljenost, smanjeno samopoštovanje ili kroničnu depresiju (usp. DeRushia, 2010, str. 4).

Budući da je internet tako nevjerojatno bogata riznica informacija, to zapravo znači da su mnogi internetski tekstovi obično samo preuzeti, ali ne i pročitani. Do adolescencije, današnji mladi već su postali stručnjaci za brzo čitanje pri kojemu zamjećuju samo najvǎnije podatke. U prosjeku osoba provede dvije sekunde na svakoj mrežnoj stranici dok traga za informacijama (Small i Vorgan, 2008).

Prema Carru (2008), za nekoga tko je navikao „brstiti po informacijskom gustištu interneta, bilo da čita i piše e-poštu, prelijeće preko naslova i blogova, gleda video zapise i sluša podcastove ili, pak, jednostavno skače s linka na link"14, čitanje obimne proze poput Rata i mira postaje nemoguća misija. Slijedeći istu misao, engleski glumac Ralph Fiennes optužuje elektroničku komunikaciju za razrjeđivanje suvremenoga jezika „tako da rečenica koja sadrži više od jedne klauze postaje problem, kao što to postaje i riječ sa više od dva sloga" ${ }^{\prime 15}$ (Jones, 2011). Proslavljeni glumac nadalje napominje da zahvaljujući društvenim mrežama, to jest komunikaciji ograničenoj samo na slanje tekstualnih poruka, e-pošte, razmjenu trenutačnih poruka i pisanje blogova, studentima glume „gustoća Shakespeareovog teksta izgleda kao izazov s kojim se [studenti] od prije nekoliko generacija moguće ne bi suočili”"16 (ibid).

\section{Poučavanje engleskoga kao stranoga jezika (TEFL) u digitalnom dobu}

Već je nekoliko puta navedeno da je u svijetu kojim vladaju računala, mladi mozak u potpunosti reprogramiran. Nastavnici su dobro upoznati s manifestacijama takve

\footnotetext{
${ }^{14}$,foraging in the Web's info-thicket's reading and writing e-mails, scanning headlines and blog posts, watching videos and listening to podcasts, or just tripping from link to link".

${ }^{15}$ "so that the sentence with more than one clause is a problem for us, and the word of more than two syllables is a problem for us".

${ }^{16}$,find the density of a Shakespeare text a challenge in a way that, perhaps, (students) a few generations ago maybe wouldn't have".
} 
pojave, pri čemu je najočigledniji problem brzi pad koncentracije, barem kada je u pitanju slušanje dugačkih predavanja.

Društvo je integriralo digitalnu tehnologiju u svaki aspekt ljudskoga života i nastavnici EFL-a više ne mogu zanemariti tu činjenicu. Stoga je u digitalnom dobu imperativ da predavač pronađe načine kako da tehnologiju integrira u nastavu. Digitalni mediji lako su dostupni i brza su razonoda mladim mozgovima koji postaju preplavljeni sveprisutnim i pretjerano izdašnim informacijama, što rezultira nemirom i nestrpljivošću učenika u učionicama gdje tehnologija nije zastupljena. Tu su, međutim, od koristi razne aplikacije. Na primjer, točnost prevođenja u EFL učionici (iako samo za početnike do učenika s maksimalno srednjom razinom znanja) može se provjeriti instaliranjem programa iTranslate, TripLingo ili SayHi Translate koji bilo koju riječ ili rečenicu mogu prevesti izravno s Androida (učenik jednostavno piše na ekranu ili govori u mikrofon riječ, rečenicu ili tekst koje želi prevesti).

Unatoč suštinskim pomacima i u svijetu i u mladom mozgu rođenoga digitalca, škole su se posljednjih desetljeća vrlo malo promijenile (Levasseur, 2011). Velika se većina i dalje drži pisanja na ploču i frontalnoga predavanja. Taj pristup je, međutim, stvoren kako bi se riješili okolišni, socijalni i ekonomski izazovi industrijskoga svijeta, a ne digitalne ere. Nove tehnologije uglavnom se koriste za jačanje zastarjelih pristupa učenju (Resnick, 2002, str. 32). Od učenika se obično očekuje da robotski slijede mantre prethodne generacije te da tako steknu i reproduciraju znanje koje im prenosi nastavnik (Laurillard, 2002, str. 135). No, budući da ni sadašnjost, ni budućnost ne nalikuju na prošlost, rođene digitalce više nije moguće poučavati isključivo pomoću tradicionalne nastavne metode. Digitalni domorodci, koji su umreženi većinu života ili čak cijeli život, imaju malo strpljenja za klasična predavanja, postupnu logiku i upute tipa „provjerite ispredavano". Navikli su na trenutačnu brzinu hiperteksta, preuzetu glazbu, telefon u džepu, knjižnicu na prijenosnom računalu, elektroničku poštu i razmjenu izravnih poruka (Prensky, 2001, str. 3). Rođeni digitalac želi informacije brzo ili će izgubiti motivaciju i potražit će nešto drugo što će raditi. To, naravno, podrazumijeva da se metodologija EFL-a mora promijeniti i prilagoditi novom dobu, posebice zato što je digitalna era zasigurno otvorila nova vrata ne samo ljudskoj komunikaciji, već i učenju jezika. Učenici moraju dobiti mogućnost sudjelovati u širokom rasponu kritičkih i kreativnih obrazovnih praksi koje uključuju tehnologiju i medije.

Ukratko, digitalno doba potaknulo je potrebu za novim nastavnim pristupima i vještinama (usp. Compton, 2009). Svi nastavnici, ovdje nastavnici EFL-a, trebaju imati otvoren, fleksibilan pristup digitalnoj opremi i elektroničkim komunikacijskim sustavima ako žele da njihovo poučavanje ima smisla (usp. Gottschalk, 2010, str. 501). Nastavnici se moraju upoznati s novim računalnim tehnologijama i digitalnim dijalogom ako žele izgraditi jače veze sa svojim učenicima. Tek tada će nastavnici moći razumjeti i bolje se odnositi prema mladima koje obrazuju (Sprenger, 2009, str. 34). Poanta je u tome da će opsesija tehnološkim proizvodima opstati, zapravo, $s$ vremenom će biti još veća. Na horizontu se već nazire primicanje nove stvarnosti predočene 3D 
ispisom i ostalim inovacijama. Ako se složimo s napomenom Ralpha Ellisona da je „obrazovanje građenje mostova”, ${ }^{17}$ tada bismo trebali svesrdno podržati Levasseurov komentar (2011) da „nijedan most nije važniji od mosta koji vodi u budućnost”"18. S obzirom da je trenutačno stanje takvo da će nam budućnost biti digitalna, nastavnici moraju preispitati poučavanje i učenje EFL-a, koji se u većoj mjeri oslanjaju na digitalne tehnologije.

\section{Ponovno osmišljavanje EFL-a: od obrazovanja usredotočenoga na učitelja do obrazovanja usmjerenoga na učenika}

Svijet TEFL-a sve se više premješta na internet, gdje nastavnici EFL-a mogu podijeliti materijale i iskustva, i biti nadahnuti kao nikad ranije. Nesumnjivo je da računala mijenjaju i da će tek mijenjati način na koji ljudi uče strani jezik. Usprkos tome, integriranje digitalnih tehnologija u obrazovnu praksu nije jednostavan proces (Mishra i Koehler, 2006, 1018; Akay, 2018, str. 431).

Novi mediji omogućuju da se fokus pažnje usmjeri na učenika, umjesto na predavača. Takvo obrazovanje poboljšava motivaciju učenika za učenjem. Internetska generacija posebno cijeni neovisnost i slobodu izbora. Učenici uživaju u razgovoru, a ne predavanju. Žele se zabaviti, čak i u školi (Tapscott, 2009, str. 6-7). Zabava ovdje znači da se informacije dobivaju stvarno brzo, da usporedno teku taj proces i višezadaćnost, da grafika prethodi tekstu, a ne suprotno, da se nasumično pristupa sadržajima (npr. hipertekst), da je prisutna umreženost, da su nagrade trenutačne i česte itd. (Prensky, 2001, str. 2). Zadovoljstvo, na kraju krajeva, mora biti dio učenja ako se teži učinkovitosti učenja. To logički podrazumijeva da se nastavnik razvija. Prema riječima Fullana (2006, str. 324) proces usavršavanja označava „razvijanje novog uvida u pedagogiju i pedagošku praksu, te istraživanje novih ili naprednih razumijevanja [nastavnih] sadržaja i sredstava"19.

Iako je tehnologija pouzdani izvor užitka za mladu generaciju, dugoročno gledano to ne bi trebao biti jedini izvor ugodnih iskustava u okruženju za učenje. Otići u drugu krajnost, naime, moglo bi biti kontraproduktivno. U tom pogledu, Phillips (2015, str. 318) upozorava na često nekritičke pohvale upotrebe digitalnih tehnologija u učionicama, za koje se tvrdi da „imaju sposobnost unapređenja podučavanja i učenja” ${ }^{20}$. Ironično je da su digitalne hardverske i softverske kompanije najčešće sponzori reklamnih kampanja koje zagovaraju obrazovnu uporabu digitalnih tehnologija, pretežno u razvijenim zapadnim zemljama. Stoga je od ključne važnosti da nastavnik EFL-a omogući

\footnotetext{
17 „education is a matter of building bridges”.

${ }^{18}$ "no bridge is more important than the bridge to the future”.

${ }^{19}$ „develop[ing] new insights into pedagogy and their own practice, and explor[ing] new or advanced understandings of content and resources".

${ }^{20}$ "have the capacity to enhance $[\ldots]$ teaching and learning $[\ldots]$ ”.
} 
interakciju između tri oblika znanja: tehnološkoga, pedagoškoga i sadržajnoga (Mishra i Koehler, 2006, str. 1025). Istovremeno EFL učenike treba poticati da uravnoteženo primjenjuju digitalne alate i komunikaciju licem u lice. U protivnom, učenici bi se međusobno mogli družiti jedino kao avatari, to jest mogli bi potpuno zaboraviti da na drugoj strani ekrana postoje stvarni ljudi sa stvarnim emocijama (usp. Gottschalk, 2010, str. 501). Sve u svemu, učenici trebaju naučiti kako ostati usredotočeni, kako pažljivo slušati drugoga i uspostavljati kontakt očima te ne prekidati sugovornika, što bi im trebalo pomoći u izgradnji socijalno-emocionalne pismenosti koja im obično nedostaje. Nadalje, važno je potaknuti učenike da svojemu umu dopuste da se ponovno zaokupi opisima, pripovijedanjima i raspravama. Ali da bi se to postiglo, u nastavni proces EFL-a treba uključiti visokotehnološke i niskotehnološke aktivnosti. To naravno podrazumijeva da je nastavnik ne samo računalno pismen i da se u nastavi koristi digitalnom tehnologijom, nego i da učinkovito koristi tehnologiju u svojoj nastavi (usp. Phillip, 2015, str. 319).,,Takav je nastavnik sposobniji u prenošenju znanja svojim studentima, s obzirom na to da mu je lakše implementirati moderne metode i tehnike [...]. Osim toga, takav nastavnik stalno komunicira sa studentima, s obzirom na to da im može biti na raspolaganju bez vremenskog i prostornog ograničenja" (Dobrota i Benković, 2014, str. 105). Jednostavnije rečeno, iako „tehnologija neće zamijeniti nastavnike, nastavnici koji koriste tehnologiju vjerojatno će zamijeniti nastavnike koji to ne čine"21 (izjava je sa skupa Učenje pomoću tehnologije održanog u Glasgowu, 26. i 27. ožujka 2013. godine).

U svojoj ulozi nastavnika, iz prve smo ruke iskusili prednosti uvođenja tehnologije i medija u učionicu. Za početak treba reći kako klasični udžbenici odbijaju novu generaciju, dok ih oslanjanje na internet i druge elektroničke alate, razumljivo, nadahnjuju. Mehanizam koji stoji iza ovoga fenomena je jasan: čini se da se internetska generacija hrani tehnologijom i da ima sposobnost apsorbirati sve što je digitalno (Tapscott, 2009, str. 10). Korištenje besplatnih internetskih alata koji olakšavaju nastavu jedno je od čuda poučavanja u digitalno doba. Iz toga proizlazi jasan zaključak da je dugoročno neuspjela strategija potpuno isključiti korištenje elektroničkih tekstova, glazbe, filmova itd., koji su postali novi mediji za prenošenje znanja. Navedeni se resursi umjesto toga trebaju koristiti u korist učenja EFL-a. No, računalno potpomognute metode i tehnike poučavanja (usp. Dobrota i Benković, 2014, str. 105) najprije zahtijevaju liberalizaciju kurikula (Krimer-Gaborović, 2009, str. 321), a zatim i široku primjenu učenja jezika pomoću računala (CALL) u učionicama (Mišić-Ilić i Mihajlović, 2011, str. 470). Dok prvo podrazumijeva opsežno korištenje audiovizualnih materijala, PowerPoint prezentacija, istraživačkih metoda i dr., u vezi sa zanimljivim temama (što uvijek ovisi o sposobnostima, vještinama, znanju i preferencijama ciljne publike), drugo za cilj ima uvođenje praktičnije orijentiranih tečajeva koji će integrirati suvremenu informacijsku tehnologiju učenja s jedne strane i učenje EFL-a s druge strane. Tako, primjerice,

\footnotetext{
${ }^{21}$ „technology won't replace teachers, teachers who use technology will probably replace teachers who don't”.
} 
učenik koji se bavi istraživačkim radom (ili projektom) može naučiti kako svrhovito pretraživati izvrsne baze podataka na internetu, kako procjenjivati, mijenjati i koristiti pronađeni materijal i kako iskoristiti mogućnosti računalno podržane komunikacije i učenja na daljinu u svrhu učenja EFL-a. To je pomak s obrazovanja usredotočenoga na učitelja/nastavnika. Nastavnik je i dalje prisutan u kontekstu koji je usredotočen na učenika jer je nastavnik taj koji pokreće i strukturira iskustvo učenja.

Sada ćemo najprije dati kratki pregled praktičnih implikacija liberalizacije kurikula EFL-a, a zatim u svezi s tim, razmotrit ćemo neke od konkretnih primjera primjene CALL-a u nastavi EFL-a. Ako je kurikul zamišljen kao zbroj svega što se događa u školi, onda on posjeduje i dinamičniji aspekt. Uostalom, učenje je inherentno u stalnom kretanju, to jest promjenjivo je i dinamično. To je dokaz da se digitalna stručnost današnjih učenika može transferirati u praksu samo prilagodbom nastave EFL-a bogatstvu internetskih podataka. Prema Levasseurovim riječima (2011), glavni bi obrazovni cilj 21. stoljeća trebao biti oblikovanje jasnoga i sveobuhvatnoga pogleda na svijet. Sve skupa to podrazumijeva da bi moderno obrazovanje trebalo imati cilj njegovanje digitalne ili nove medijske pismenosti (tradicionalna pismenost je osnova, ali ona više nije dovoljna). To također podrazumijeva suradnju na društvenim mrežama, kolektivno udruživanje znanja, kretanje i pregovaranje između različitih zajednica te kritičku analizu i usklađivanje konfliktnih dijelova informacija koje je moguće kodirati usmeno, u tekstu, slikama, simulacijama itd. To nadalje znači da je za bavljenje određenom temom, primjerice rad na jednostavnoj ELF aktivnosti kao što je poučavanje leksika vezanoga za vremenske prilike i nepogode, potrebno napustiti stari ekskatedra stil predavanja, gdje je učitelj izvor znanja. Umjesto toga, učenike treba uputiti i ohrabriti da pretražujući internet pronađu informacije o vremenskim pojavama. Zgodna mrežna stranica u ovom slučaju je stranica s tematskim pjesmama na kojoj se može pretraživati tekst pjesme u vezi sa zadanom temom. Mnoštvo materijala već je dostupno na engleskome jeziku, što čini zadatak poučavanja EFL-a doista ugodnom aktivnošću.

Takav način predstavljanja lekcije odmah će potaknuti učenikovo aktivno sudjelovanje u radu na zadanim temama. Mudri nastavnik EFL-a nikada neće smetnuti s uma da je računalo najvjerniji pratitelj digitalne generacije. Općenito, EFL aktivnosti uz primjenu CALL-a omogućuju „učeniku da samostalno donosi odluke te mu tako pružaju autonomiju, osjećaj moći i mogućnost aktivnog sudjelovanja u procesu učenja jezika"22 (Furstenberg, 1997, str. 22). Isto tako pomaže učenicima da zadatke rade u parovima, po troje ili u timovima, a ne pojedinačno. To će pospješiti njihovu komunikaciju licem u lice. Da bi riješili domaće zadaće, članovi grupe možda će se morati povezati i komunicirati telefonski, putem e-pošte ili neke druge elektroničke komunikacije, osobno ili kombinirajući sve ove metode.

Potrebno je naglasiti da, iako je pisani jezik interneta i tekstualnih poruka obično nestandardan, nastavnik EFL-a treba imati doista široko razumijevanje namjena 22 ,the learner to make choices and thus provides autonomy, a sense of empowerment, and the opportunity to
become an active participant in language learning”. 
kojima bi takav jezik trebao služiti. Ukratko, nastavnik bi ispočetka trebao dopustiti „rastezanje jezika” kako bi pobudio interese učenika za učenje EFL-a i pomogao im da ostanu usredotočeni na nastavu. S obzirom na to, učenici EFL-a će sigurno uživati u igranju, primjerice slagalica s emojijima gdje je zadatak odabrati i sastaviti rečenice ili cijeli tekst od emojija, a potom pustiti druge da pogađaju značenje onoga što vide. Kada se probudi interes, postiže se prvi nastavni cilj, a predavanje EFL-a može krenuti u smjeru ozbiljnijih jezičnih rasprava. U protivnom, bit će teško uvjeriti suvremene učenike priviknute na višezadaćnost da se uopće pozabave formalnim jezikom i književnim stilom.

\section{Rješavanje problema: naprave koje olakšavaju učenje EFL-a}

Na mreži se svakodnevno pojavljuju novi uređaji ili besplatni internetski alati koji čine nastavu jednostavnijom, boljom ili jednostavno zabavnijom (Starr, 2012). U tekstu ispod slijedi prikaz najboljih načina za maksimiziranje učinkovitosti tehnologije u jezičnoj učionici. Naime, EFL nastavnici morali bi se služiti navedenim alatima ako žele izvući koristi za učenje EFL-a u okruženju digitalnoga kaosa i terora. Treba, međutim, znati da prikazani popis mrežnih EFL alata ni u kom slučaju nije potpun (temelji se prije svega na radovima Starra (2012) i Tynana (2005)):

Motivator: alat koji nastavnicima EFL-a omogućava da za otprilike tri minute naprave motivacijski plakat. Inspirativni plakat može se dobiti postavljanjem fotografije, isticanjem naslova i kratkoga teksta itd.

Wordie: EFL nastavnik odabire bilo koji tekst ili niz riječi i kopira ih u tekstni okvir na mrežnoj stranici. Tako se stvara grafički prikaz riječi, a veličina svake pojedine riječi određuje se shodno njenoj učestalosti u izvornom nizu riječi. Alat se može koristiti, primjerice, za prikazivanje pravila ponašanja $u$ učionici i očekivane razine jezične kompetencije za ovladavanje nastavnim sadržajem u grupi. K tome, učenici mogu koristiti ovaj alat za stvaranje jedinstvenih izvještaja o knjigama, bilješki o učenju jezika ili pak za analizu vlastitog pisanja, primjerice provjere pretjerano korištenih riječi itd.

WordSift: predstavlja savršeniji oblik korištenja Wordlea. Nakon što učenik EFL-a (koji recimo ima problema s čitanjem) unese svoj tekst, kreira se oblak riječi kao i mrežne riječi i slike.

Let Me Google That for You: zabavno sredstvo koje vole i nastavnici i učenici EFL-a. Ako učenici (ili nastavnici) imaju poteškoće u pronalaženju određenih podataka, poput razlike između morfema i morfa, ovaj posebni uređaj može ih navoditi gdje mogu pronaći odgovarajuća objašnjenja.

Zap Reader: internetska aplikacija koja se koristi kada treba brzo obraditi velike količine teksta.Zap Reader omogućuje korisnicima da kopiraju i prenesu tekst u tekstni okvir, a zatim ga komprimiraju. Program u osnovi stimulira brže čitanje kod lošijih čitatelja, to jest povećava tempo kojim učenik može tiho čitati tekst. $S$ vremenom alat ne samo da je od koristi za unapređenje vještine čitanja, već također potiče bolje razumijevanje 
pročitanoga. Učenici mogu započeti vježbati tempom koji im je najugodniji, a onda polako povećavati brzinu. Poticanje učenika na glasno čitanje ne samo da poboljšava tečnost čitanja, već pospješuje i mogućnost izražajnoga čitanja.

Blogger: Googleov besplatni alat za objavljivanje mrežnih blogova ondje gdje postoji mogućnost dijeljenja teksta, fotografija i videozapisa. Može se lako upotrijebiti kao komunikacijska odskočna daska za izvanškolska natjecanja, istraživačke projekte, zadatke kojima učenici stječu dodatne kredite, ažuriranje popisa odsutnih učenika, komunikaciju $\mathrm{s}$ roditeljima o atmosferi u razredu i još mnogo toga. Uza sve to, roditelji su otkrili da je Blogger poželjan alat za poticanje motivacije za izvanškolsko učenje. Mrežna stranica vodi korisnike kroz izradu bloga, a može ga se prilagoditi na različite načine.

Mindomo: internetski alat za misaone karte koje služe za vizualno učenje, poboljšanje kreativnosti i rješavanje problema. Korisnici mogu napraviti dijagrame protoka ideja o bilo kojoj temi koju žele obraditi, a zatim stvoriti podteme, multimedijske veze i još mnogo toga. YouTube videozapisi prikazuju se izravno na mapi koju je moguće poništiti ili proširiti, moguće je fokusirati se na jedan po jedan odjeljak, doista je bezbroj mogućnosti. Ovaj alat koristan je za projekte u razredu, primjerice istraživanje o obitelji. Misaone karte potiču protok ideja i razumijevanje ideja koje se vrte oko zadane teme, na primjer aspekte obiteljskoga života koje učenici smatraju važnim mogu prikazati kroz svoje projekte (usp. Sliku 2). S naprednim učenicima EFL-a to mogu biti i konceptualne mape koje će ih naučiti povezivanju pojmova, npr. piramide $\longleftrightarrow$ drevni Egipat $\longleftrightarrow$ kraljevske grobnice $\longleftrightarrow$ kripte $\longleftrightarrow$ smrt i tako dalje.

Slika 2.

Ukratko, misaone karte poučavaju učenike EFL-a da istražuju i organiziraju misli, ideje i informacije i odluče što je važno i kako se to povezuje s onim što već znaju. Tako se razvija kritičko mišljenje. Ostali internetski alati za kreiranje misaonih karata koje vrijedi razmotriti su Mindmaps, Bubbl.us, Mindmeister, WiseMapping.

Grammarly: još jedan zgodan alat. Svojim čudesnim mogućnostima uređivanja teksta Grammarly omogućuje učenicima da se pozabave svojom vještinom pisanja s obzirom da automatski nudi rješenja za pogrešno napisane riječi i besmislene rečenice (stalno ukazuje na pogreške).

Langroo: jednostavan i pristupačan alat koji ima ulogu „prijatelja-izvornog govornika engleskoga jezika". Poučava učenike konverzacijskom engleskom jeziku zastupljenom na teritoriju Velike Britanije s jedne, i SAD-a s druge strane, bez obzira na to je li riječ o učeniku početniku koji traži neke osnovne izraze „za preživjeti” ili je to napredni učenik zainteresiran za hipsterski žargon. Zgodno smješten unutar Facebook Messengera, i uz 24-satnu dostupnost, Langroo ima za cilj omogućiti učenicima da svladaju jezične barijere i pogreške. U ponudi su dva naglaska - američki engleski i britanski engleski, što znači da učenik može birati i jedan i drugi te tako temeljito ovladati razumijevanjem njihovih razlika. 
Općenito, alati koji olakšavaju poučavanje EFL-a također bi se mogli upotrijebiti da se učenicima pruži prilika da samostalno istražuju i otkrivaju. Umjesto da ih se poučava kako odgovoriti na pitanje, učenike bi trebalo poučiti kako da više pitaju. Nakon suočavanja s pravovremenim i relevantnim dilemama, trebalo bi ih stimulirati da vlastito rješenje problema pronađu pomoću mrežnih (i eventualno) drugih dostupnih alata. Tako se njeguju kritičko razmišljanje, funkcionalne vještine i znanje. Naravno da EFL nastavnik i dalje treba pratiti učenički rad, davati povratne informacije i odgovarati na upite.

Pored toga, kod učenja utemeljenoga na rješavanju problema, postoji tendencija da se nastavni sadržaji uče temeljito. Takvo učenje, nadalje, omogućuje učenicima EFL-a da na zajedničkom mrežnom prostoru oglase svoja rješenja, to jest zaključke do kojih su došli te da ih potom eventualno i argumentiraju pred kritikom drugih članova grupe. Naravno, ne može se sve poučavati ni učiti na ovaj način, primjerice čitanje se neće obrađivati tako što će se učenici povezati na internet da bi raspravljali o tome kako različito interpretiraju značenja jedne riječi.

\section{Zaključne napomene}

U radu se obrazlaže položaj engleskoga jezika kao istaknutoga jezika koji se uči u cijelom svijetu. Engleski je također lingua franca na internetu i u posljednje vrijeme doživljava eksponencijalno rastuću promjenu.

U radu se također pokušava detaljnije ispitati različite aspekte poučavanja EFL-a kod nove generacije učenika. Brz rast tehnologije donio je mnoge inovacije u obrazovanju, a posebice u nastavi EFL-a. Budući da je digitalna stručnost važan dio svijeta rođenih digitalaca, nastavnici EFL-a trebali bi početi uvažavati tu činjenicu u korist EFL predavanja. U učionicama u kojima dominira kontinuirana djelomična pažnja, tradicionalni ili ekskatedra pristup poučavanju EFL-a mora se osuvremeniti uvođenjem računalno potpomognutih aplikacija (CALL) i korištenjem interneta.

To isto tako znači da treba iskoristiti nove jezične stilove i forme koji su nastali pod utjecajem interneta i drugih digitalnih medija kako bi se probudio interes učenika za ozbiljnija jezična pitanja. Suvremeni višezadaćno orijentirani korisnici interneta (multitaskeri) mogu se uvjeriti da se s formalnim jezikom i književnim stilom vrijedi pozabaviti samo ako nastavnik EFL-a dozvoli ,jezičnu rastezljivost” za podršku projektima kurikula, poput kreativne uporabe internetskoga engleskog jezika, miješanih metafora i generičkih alata - Skype, Google, Tumbler, Twitter, Facebook, blogovi i Wikipedia, kao i tehnološki alati za TEFL. Ovo bi trebalo pomoći da se pobude interesi učenika za učenje EFL-a i da ostanu usredotočeni na učenje. Nakon što se ti ciljevi ispune, nastavnik može početi ozbiljnije govoriti o jeziku. 